\title{
Usury or a Consumer Convenience? \\ Historicizing the Payday Loan
}

$$
\text { by }
$$

\section{Matthew Palmer}

A thesis submitted to the Faculty of Graduate and Postdoctoral Affairs in partial fulfillment of the requirements

for the degree of

Master of Arts

in

Political Economy

Carleton University

Ottawa, Ontario

(C) 2011

Matthew Palmer 


$\begin{array}{ll}\begin{array}{l}\text { Library and Archives } \\ \text { Canada }\end{array} & \begin{array}{l}\text { Bibliothèque et } \\ \text { Archives Canada }\end{array} \\ \begin{array}{l}\text { Published Heritage } \\ \text { Branch }\end{array} & \begin{array}{l}\text { Direction du } \\ \text { Patrimoine de l'édition }\end{array} \\ \begin{array}{l}\text { 395 Wellington Street } \\ \text { Ottawa ON K1A ON4 } \\ \text { Canada }\end{array} & \begin{array}{l}395, \text { rue Wellington } \\ \text { Ottawa ON K1A ON4 } \\ \text { Canada }\end{array}\end{array}$

Your file Votre référence

ISBN: 978-0-494-83091-8

Our file Notre référence

ISBN: 978-0-494-83091-8

NOTICE:

AVIS:

The author has granted a nonexclusive license allowing Library and Archives Canada to reproduce, publish, archive, preserve, conserve, communicate to the public by telecommunication or on the internet, loan, distribute and sell theses worldwide, for commercial or noncommercial purposes, in microform, paper, electronic and/or any other formats.

The author retains copyright ownership and moral rights in this thesis. Neither the thesis nor substantial extracts from it may be printed or otherwise reproduced without the author's permission.

L'auteur a accordé une licence non exclusive permettant à la Bibliothèque et Archives Canada de reproduire, publier, archiver, sauvegarder, conserver, transmettre au public par télécommunication ou par l'Internet, prêter, distribuer et vendre des thèses partout dans le monde, à des fins commerciales ou autres, sur support microforme, papier, électronique et/ou autres formats.

L'auteur conserve la propriété du droit d'auteur et des droits moraux qui protège cette thèse. $\mathrm{Ni}$ la thèse ni des extraits substantiels de celle-ci ne doivent être imprimés ou autrement reproduits sans son autorisation.
In compliance with the Canadian Privacy Act some supporting forms may have been removed from this thesis.

While these forms may be included in the document page count, their removal does not represent any loss of content from the thesis.
Conformément à la loi canadienne sur la protection de la vie privée, quelques formulaires secondaires ont été enlevés de cette thèse.

Bien que ces formulaires aient inclus dans la pagination, il n'y aura aucun contenu manquant.

\section{Canadä}




\begin{abstract}
This thesis contributes to a genealogy of usury by exploring the rise and impacts of payday lending in the Canadian context. By examining the legislative discourse surrounding usury over the past century, the various practices of usury themselves, and the current attempts to regulate the impacts of payday lending through financial literacy, the work argues that the growth of payday lending has been accompanied by and has supported a novel understanding of the relationship between poverty and high-interest lending. It contends that contemporary attempts to regulate this sector are founded on a homogenous conception of the consumer that obscures many structural economic issues that previous approaches highlighted. Finally, it shows that the work of some banks and credit unions that seek to offer alternatives to payday lending are redeploying historical notions of thrift and social investment which challenge the intellectual foundation on which payday lending and financial literacy currently sit.
\end{abstract}




\section{Acknowledgements}

This thesis simply would not have been possible were it not for the numerous individuals and organizations that have helped me along the way. Many thanks to my supervisor, Professor William Walters, whose initial enthusiasm for the project convinced me to stick with it and whose critical comments along the way helped to shape its direction. Thanks to Carleton's Institute of Political Economy for creating such a welcoming space where students can explore their interests and have all the support they need. This is in large part due to the tireless work of the Institute's administrator, Donna Coghill and its Director, Professor Janet Siltanen. Thanks also to Professor Randall Germain, whose comments on earlier drafts of the thesis helped to solidify the argument and helped me gain perspective on its position within the field. For their financial support for the project, I would also like to thank the Social Sciences and Humanities Research Council and the Ontario Graduate Scholarship Program. Lastly, thanks to Adèle Michon for helping to keep me sane, grounded and smiling throughout this process. 


\section{Table of Contents}

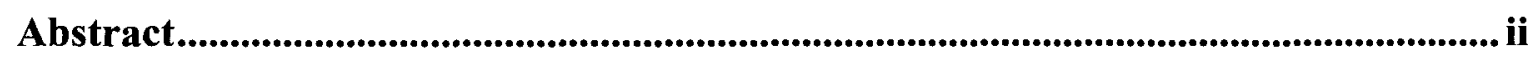

Acknowledgements .......................................................................................................................ii

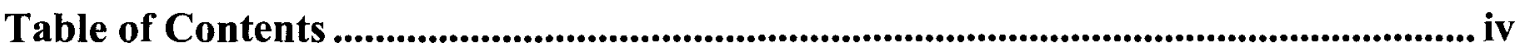

List of Figures................................................................................................................................... v

List of Appendices................................................................................................................ vi

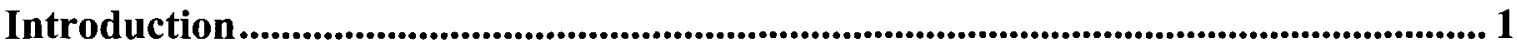

Payday Loan Background.......................................................................................................... 2

Approaching this Problem .................................................................................................................. 3

Post-Structural Toolset ......................................................................................................................... 7

Genealogy

Knowledge, Power, Discourse and Governmentality …………………………………..... 9

Chapter 1: Debating Usury .......................................................................................................... 17

Legislating Usury .................................................................................................................... 18

The Logic of Contestation ............................................................................................................... 20

Articulating the Clientele ........................................................................................................... 23

Articulating Possibilities for Broader State Intervention ..................................................... 26

Liberal Governance and the Payday Lending 'Industry' '...................................................... 28

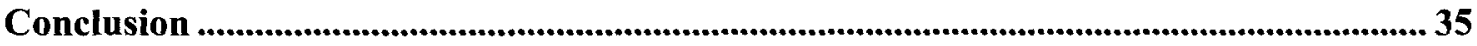

Chapter 2: The Event of Borrowing................................................................................37

Pawnbrokers: An Age Old Lender of Last Resort ................................................................ 39

Payday Lenders: The Most Recent Addition to the Consumer Financial Landscape ...... 40

Positioning Fringe Finance ......................................................................................................... 41

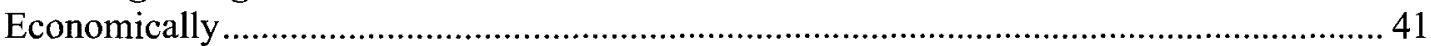

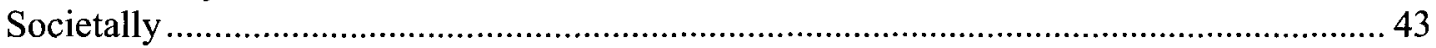

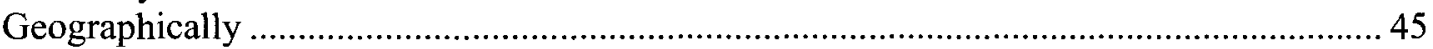

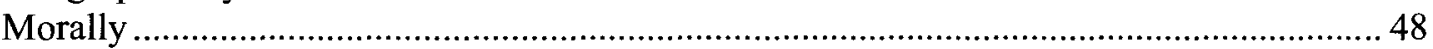

Constituting the Subject...................................................................................................................5 52

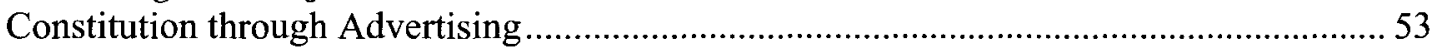

Constitution through the Event of Borrowing ..................................................................5

Constitution through Collections .................................................................................... 59

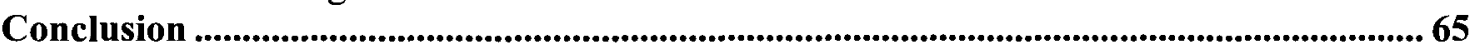

Chapter 3: Governing Usury ................................................................................................ 68

The Problem of Financial Literacy ........................................................................................ 69

Responsibilization through the Generations - Thrift, Consumption and Financial

Literacy ............................................................................................................................. 71

The FCAC and the Politics of Financial Literacy.....................................................................87

Contesting Financial Literacy .................................................................................................... 92

Conclusion ...................................................................................................................... 101

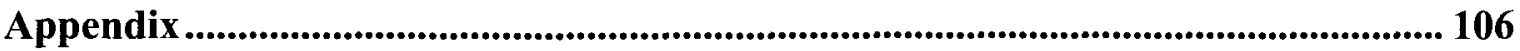

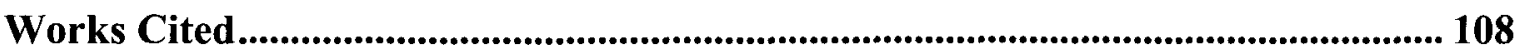




\section{List of Figures}

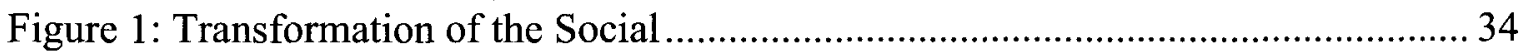

Figure 2: Money Mart Brochure ............................................................................ 54

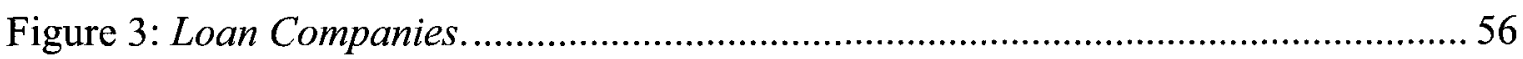

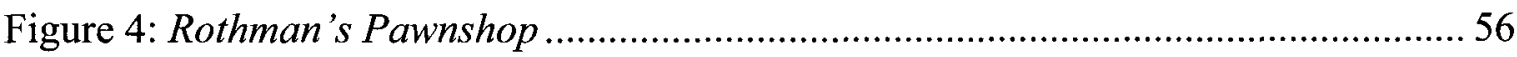

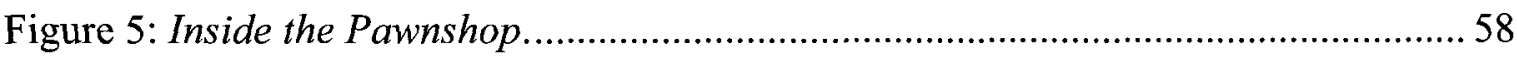

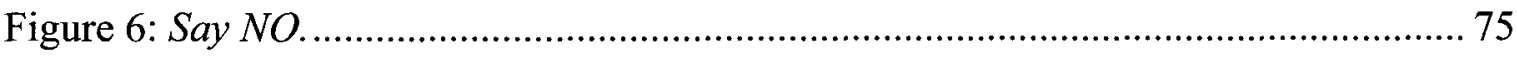

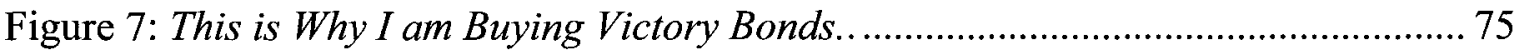

Figure 8: Number of Selected Fringe Financial Services and Mainstream Banks/Credit Union Branches in Winnipeg's North End, 1980-2003 ............................................ 94 


\section{List of Appendices}

Appendix I) Letter to Collection Agencies from Ontario Ministry of Small Business and Consumer Affairs....................................................................................... 106 


\section{Introduction}

This bill is intended to give a certain amount of protection to parties whose financial circumstances are such that they are unable to protect themselves. It also recognizes the fact that loans to such parties are, to some extent at least, of a desperate character....It is with the view of protecting the men who otherwise are unable to protect themselves" (Hon. Mr. Mills, during a Canadian Senate Debate regarding An Act Respecting Usury, May 8, 1900)

This does not mean that loan sharks will have a field day. This means that genuine lending businesses, which I described as payday loan operations, can carry on with their legitimate lending services in cities and localities across the country, just as they have up until now, without fear that their practices will offend the criminal law. (MP Derek Lee, during a House of Commons Debate regarding the passage of Bill C-26 exempted payday lending from criminal usury provisions, Nov. 6, 2006)

The payday loan industry is novel and worthy of study for a number of reasons. As the quotes above highlight, never before in Canadian history have high-interest shortterm loans been so widely available, legitimate and legally recognized. The industry has gone from being non-existent in Canada twenty years ago to today being a large and profitable presence in the consumer financial landscape. According to the Canadian Payday Loan Association (CPLA, the national industry body which represents over 600 retail payday loan outlets nationwide), there are today over two million Canadians who use the service annually (CPLA, 2011). Industry leader Dollar Financial Corp., which operates the national Money Mart chain, recently announced record quarterly results and the sector has continued to grow rapidly despite the financial collapse of 2008-2009 (Business Wire, 2011). Cash Store, for instance, a national chain that had only 415 stores in 2009 today has 566 (Cash Store Financial, 2010). When this number is combined with the 419 Money Mart locations (Dollar Financial Corp., 2011) nationwide and all of the mom and pop outlets, conservative estimates would suggest that there are well over 1400 
retail payday lenders in the country today. There is a lack of industry-wide data regarding this sector's economic impact, but estimates suggest that $\$ 2$ billion is annually lent by these operations in Canada (Government of Ontario, 2009) and that the industry's revenues range somewhere from $\$ 170$ million to $\$ 1$ billion (Kitching \& Starkey, 2006). While these figures are marginal when compared to the roughly $\$ 380$ billion that the big six Canadian banks lent to consumers last year (PWC, 2011), the fact that this industry occupies such a precarious position between the worlds of usury and mainstream finance makes it worthy of critical investigation. The following thesis will offer an analysis of this industry, looking at questions regarding its emergence as a mainstream element of the financial world and what consequences this has had regarding how we think about the problems surrounding high-interest lending, the people it impacts and the effects that it has on society. It will delve into the changing ways in which our society has tried to deal with these problems over time and finally offer some analysis regarding the ways in which this sector is currently being directly contested by community development organizations, NGOs and mainstream financial institutions.

\section{Payday Loan Background}

The payday loan is a financial instrument wherein an uncollateralized short-term salary advance is given without the typical credit check that would be performed at a mainstream financial institution. Normally, the payday lender requires the applicant's most recent pay-stub, a record of their recent bank transactions, and a post-dated cheque before the loan is approved. If the applicant is deemed acceptable, the payday lender provides cash amounting to a certain percentage of the borrower's bi-weekly income. According the Canadian Payday Loan Association (CPLA), the value of the average 
payday loan in Canada is roughly $\$ 280$ and the loan is taken for an average period of ten days (CPLA, 2011). If one calculates the total annual interest rate plus fees on these loans, they typically range anywhere from roughly 390 to 780 percent (Stegman, 2007, p. 169) with the average in Canada being 435 percent (Pyper, 2007). ${ }^{1}$ This interest rate is complicated though, when one considers the borrower's option to 'roll-over' these loans, wherein they pay only the fees/interest on the loan and continue to hold the principal, thus incurring another set of fees/interest. Because of these roll-overs, estimates from the United States suggest that the average payday loan borrower repays $\$ 793$ for a $\$ 325$ loan (Paterson, 2008, p. 1127). In Canada, many provinces have imposed legislation banning roll-overs, however there still remain jurisdictions where this industry is largely unregulated.

\section{Approaching this Problem}

To date, there has been much in the way of mainstream economic and political analysis regarding the problems associated with payday loans. Economists have studied the profits of payday lending firms (Skiba \& Tobacman, 2007), the economic costs associated with the 'debt trap' that some borrowers find themselves in (Ernst, et al., 2003), the causes of demand for the sector (Skiba \& Tobacman, 2008), and whether the economic costs of providing the service justify the high interest rates felt by borrowers (Flannery \& Samolyk, 2005). There have been geographical analyses done of the

\footnotetext{
${ }^{1}$ It should be noted that the interest rate for these types of loans is not a completely objective statistic. The way in which it is calculated - whether it is in annual terms or those more closely related to the length of the loan period - is highly contested and even differs across provincial jurisdictions within Canada. For consistency with both the Canadian Criminal Code provisions on usury and truth in lending legislation, this study will refer to interest rates in annual terms.
} 
locations of payday lending outlets (Prager, 2009) and legal scholars have analyzed the efficacy of legislation pertaining to the sector (Ziegel, 2003). While many of these studies offer interesting insights, none of them, in my view, offer a substantive critical historical analysis. They often take for granted the payday loan's existence as a legitimate element of the financial industry, without fully analyzing the nuanced historical processes by which it emerged. Even some of the critical articles in this school which emphasize trends such as the neo-marxian concept of exploitation (for instance, Mayer, 2003), rely on ahistorical economic categories in their analysis; by scientifically defining exploitation, one disregards the ways in which the publicly legitimate experience of the payday loan is substantial in separating it from analogous historical 'exploitative' practices such as loan sharking.

Outside of this quantitative, econometric and legal literature, there exists a wide array of authors who have analyzed this issue from critical theoretical perspectives. Within the Marxian school, some analysts have taken a macro perspective in analyzing how changes in the structure of the global economy have increased the importance of finance capital; as post-war Keynesian debt-financing has been replaced by a more flexible regime, it is argued that finance has come to the fore as the primary means of staving off crises of accumulation (Guttmann, 2008). "New financial instruments and markets" have emerged, "coupled with... highly sophisticated systems of financial coordination" as a temporal fix to this volatile capitalist world system (Harvey, 1990, p. 194). At a policy level, it is argued that there has been a "shift towards institutional structures...that reflect the interests and growing power of finance capital" (Harmes, 2001, p. 104). As a result, it is said, the banking sector has been largely deregulated and 
new 'predatory' financial services, such as the subprime mortgages and payday loans have proliferated. Personal debt levels have risen dramatically and regular working class individuals have been increasingly involved in the previously exclusive world of finance (Bellamy Foster, 2006).

At a more local level, there have been extremely interesting neighbourhood level analyses done of the rise of 'fringe finance' services such as payday lending. Buckland and Martin (2005) for instance, in their article 'Two-Tier Banking: the Rise of Fringe Banks in Winnipeg's Inner City' look at the ways in which a combination of supply and demand side factors came together to create a situation wherein fringe banking could thrive in the city's North End neighbourhood. On the supply side, it is argued that bank closures in the 1990s and early 2000 s left poor neighbourhoods with limited access to mainstream banking services (p. 11); even when people were able to make it to a bank, factors such as stigmatization (p. 14) and identification requirements (p. 12) made fringe finance a more appealing option. On the demand side, low incomes, debt spiral problems and inadequate credit options are said to have contributed to the situation today (p. 1720). While both these macro level and micro level critical analyses are quite illuminating insofar as they expose some of the structural economic factors that have made the current expansion of the industry possible, one cannot gain a full appreciation of these changes without taking a nuanced look at the ideational factors that have accompanied them.

At a theoretical level, some Marxian scholars have historically suffered from weaknesses in their ability to describe the ways in which human subjectivity is formed. While at a macro level, causal analyses focusing on the structure of global capitalism, class domination, and the contradictions inherent in a capitalist system reveal many 
interesting insights, theoretical shortcomings surrounding how the subjects of capital relate to this system over time makes a nuanced analysis of historical change difficult. I have no interest in understating or simplifying the array of approaches that different Marxian schools of thought have developed on this issue; they are indeed numerous and all involve their own complexities. Some emphasize false consciousness, others alienation, and others the hegemony of ideas. Althusser (2005), whose analysis heavily emphasized 'ideology' even brought in the concept of overdetermination to offer further nuance to the picture. Despite all of these variations, though, capital remains at the heart of many Marxian analyses and thus, even if it is 'in the lonely hour of the last instance' the primary causal force driving history. By understanding capitalism as a totalizing and universal system - as the primary subject of historical analysis - these approaches often fail in my view to offer an adequately complex and nuanced account regarding the importance of subject-formation and contingency in historical change. By looking at the complicated process by which payday lending has emerged as a legitimate consumer service, it is my hope that this becomes clear. Focusing on one particular site, in this case usury, where ideas about economy, morality, politics and class vividly intersect allows one to gain a rich appreciation of the complexity by which processes of subject-formation and historical change unfold.

Historically, the attitude toward usury kept changing with the times. A transaction condemned in one historical period as usurious was recognized as a normal economic practice in another. And practices among countries varied. Practices outlawed and punished in one country were freely permitted in another. Thus, usury as an economic concept may be understood only in the light of the moral and legal norms prevailing in a particular period. (Kaplan \& Matteis, 1968, p. 241)

As the quote above illustrates, usury has historically been a widely debated topic 
and subject to a vast array of approaches. Its social position and regulation have been impacted by the vicissitudes of history, and thus we have witnessed dramatic changes in both how people have understood this problem and the ways in which they have sought to fix it over time. Biblical passages problematized the practice on strictly moral grounds, Dante Alighieri (1883), in Inferno, relegated usurers to the inner ring of the seventh circle of hell, and Bentham (1816) famously defended the practice on the grounds of economic liberalism. Today, the term has largely fallen out of favor in the West as interest itself has become normalized. Usury, rather than having the absolute and universal definition that it carried historically, has in the modern context taken on a relative meaning; it denotes an 'unreasonably high' rate of interest, somehow set apart from normal, just interest.

Evidently, there has been no absolute science in how societies have dealt with this issue, but rather it reflects a complex history wherein subtle shifts in how we understand economy, morality and society have come together to impact the way that we approach the problems before us. It is in this spirit that the following thesis engages with the modern phenomena of payday lending.

\section{Post-Structural Toolset}

\section{Genealogy}

At the core of this analysis lies a Foucauldian understanding of the processes by which historical changes occur. Grounded in a genealogical methodological framework, the following thesis will not rely on the assumption that the transformations in how we understand this form of lending must necessarily fit within broader theoretical narratives such as those employed by many Marxian scholars.

[Genealogy] must record the singularity of events outside of any 
monotonous finality; it must seek them in the most unpromising places, in what we tend to feel is without history - in sentiments, love, conscience, instincts; it must be sensitive to their recurrence, not in order to trace the gradual curve of their evolution, but to isolate the different scenes where they engaged in different roles. Finally, genealogy must define even those instances where they are absent, the moment when they remained unrealized. (Foucault, 1977, p. 140-141)

This project will not "pretend to go back in time to restore an unbroken continuity" of the evolution of usury or "demonstrate that the past actively exists in the present" (Foucault, 1977, p. 149). Instead, it will look at the ways in which categories, practices and bodies of knowledge have been constituted in very divergent, contingent and specific ways at different points in history. By looking at the practices of usury as 'events' divorced from overarching structures and historical constants, one can illuminate how their existence is predicated on an intersection of diverse and contingent practices and bodies of knowledge. Categories like thrift, exploitation and usury don't carry the same meaning today as they have historically, but rather have been transformed and reconstituted today through processes which the following thesis will try to understand. New categories and technologies have been invented as well - financial literacy and the notion of the 'financial consumer,' for instance - shaping the terrain on which we approach the problem of usury. By rejecting progressivism, linearity and teleology in history, the genealogical approach emphasizes the contingency and historical specificity of the way in which knowledge/power manifests in different temporal instances. As such, this thesis will attempt to make sense of the disparate instances in which we've understood the usury in different ways on their own terms and within their own historical logic. By approaching history in this way, I hope to show that our current understanding of usury is contingent and peculiar; in doing so, this project will highlight the novelty of the payday 
loan and that the thinking on this subject could have developed in markedly different ways had only very slight historical changes have occurred.

\section{Knowledge, Power, Discourse and Governmentality}

In its investigation of payday lending vis-à-vis a genealogy of usury, this project is heavily dependent on the concept of governmentality as a primary analytic. Rather than placing at the fore the changing material conditions which have happened concomitantly with alterations to how we understand fringe finance, this project is focused on the power that is produced as a result of how we conceptualize - through discourse and practice the realm of usury. Governmentality challenges us to engage with questions regarding which specific "mentalities, philosophies and other intellectual machineries" condition our understanding of 'real' problems and how we ought to engage with them (Walters, 1999, p. 314). It sheds a critical light on what is commonly seen as 'rational' and exposes the assumptions about "starting points, means and goals" on which these arguments depend (Brockling et al., 2011, p. 11). It highlights that at the most basic level, 'government' is 'both made possible and constrained by what can be thought and what cannot be thought at any particular moment in our history," and as such seeks to investigate the conditions that made these specific ways of thinking possible at different points in history (Rose, 1999, p. 8). In keeping with this analytic, the following thesis will not seek to draw causal inferences between material economic conditions and the world of finance. Instead, it will examine usury as an overdetermined site of contestation - a nexus of knowledge/power which evolves in each instance, constantly altering the conditions within which we intervene upon it. The project has the modest aims of interrogating the subtle shifts in how we have come to understand the event of the payday 
loan today and highlighting some of the political implications thereof. How is payday lending presented and understood today? Who is it said to effect? What tools are currently seen as rational in approaching this problem, and how is this departing from and/or consistent with approaches and ways of knowing that existed previously?

This approach is based on a post-structuralist understanding of power relations and the importance of knowledge in shaping the conditions within which contestation occurs. In The History of Sexuality: An Introduction (1978), Foucault gave what may have been his most concise analysis of his understanding of power. Rather than articulating it as a force which is held by some and longed for by others, Foucault characterizes power as an omnipresent and productive force which underpins all human relations. "It is produced from one moment to the next, at every point, or rather in ever relation from one point to another," he writes, it "is everywhere; not because it embraces everything, but because it comes from everywhere" (Foucault, 1978, p. 93). Power, he continues, "must be understood...as the multiplicity of force relations immanent in the sphere in which they operate and which constitute their own organization; as the process which, through ceaseless struggle and confrontations, transforms, strengthens, or even reverses them" (Foucault, 1978, p. 92). If one conceives of power in this way, it becomes clear that power not only has a base in the material economic conditions of a given instance, but also the discourses, conceptual apparatuses and knowledges which constitute a given subject. If how we conceive of a certain problem - such as usury shapes the conditions within which we act upon it (i.e. governs our actions), then an interrogation of the shifts in power-knowledge on that subject becomes a necessary critical exercise. 
To date, there has been an interesting array of academic work seeking to engage with some of these cultural, ideational, and governmental aspects of the changes that have occurred in the world of finance. In 2007, Economy and Society released an entire issue dedicated to work on the cultural economy of finance, much of which drew on actor-network analysis (Pryke \& Du Gay). There have been investigations of mainstream financial products like credit cards and subprime mortgages, exposing how these instruments discipline subjects in a certain way, spawning a population which in governs itself, internalizing neoliberal notions of good citizenship (Erturk et al., 2007). Langley (2008) argues that as consumers have been further integrated into networks of everyday finance, technologies wherein the subject "embraces financial market risk... and manages risk through portfolio diversification" using calculative risk/reward measures are now pervasive (p.92). Comparatively little work has been done, though, investigating the nuances of the fringes of this sector, where finance intersects with usury - payday loans, cash chequing outlets, etc. The governmentality literature that does seek to deal with this topic has tended to do so by juxtaposing this fringe finance sector with the mainstream financial world. Aitken $(2006,2010)$, for instance, has critically examined the relationship that fringe lending has with 'finance' and the ways in which it constitutes its subjects in markedly different ways. While this literature is quite interesting, there currently exists a gap surrounding the relationship that this sector has with the longer trajectory of the discourse surrounding usury and thus the actual 'emergence' of payday lending as a legitimate entity. As such, rather than using the mainstream financial world as the reference point by which I examine payday lending, I will instead focus on the 
changing practices, knowledges and discourses that have historically made its emergence possible.

The primary methods through which this interrogation will occur in this project are both an analysis of the discourses and of the practices which serve to shape our understanding of usury. As such, it is important to theoretically elaborate on each of these facets. Firstly, with the concept of discourse, it is necessary to determine what exactly constitutes discourse and how one ought to analyze it. In the first sections of The Archeology of Knowledge (2006), Foucault defines discourse as not merely a collection of individual statements, but rather a dispersion thereof which all coalesce with some thematic regularity. As such, in an analysis of one of these discursive formations - for instance, that surrounding usury - the goal is to analyze the degree to which the statements depend on one another, "the way in which they interlock or exclude one another, the transformation they undergo, and the play of their location, arrangement and replacement" (Foucault, 2006, p. 38). In doing this, one can expose how -in very concrete terms - the approaches we bring to problems change over time as new claims to truth emerge and render new interventions rational.

This style of analysis will be done most acutely in Chapter I vis-à-vis an examination of Canadian parliamentary discourse regarding usury. The chapter takes as a methodological starting point the fact that the language we use to describe a problem and the 'regimes of truth' that surround it are not mere justifications for a concrete ideology which exists at some more fundamental level. Rather, language is viewed as "performative" in the way that it shapes how we conceive of our reality; it directly impacts the conditions within which we respond to it (Rose, 1999, p. 29). It is within this 
discursive field that we can see how the problems of government are "delineated and accorded significance;" we can examine their positioning, their changes over time, and the effects of their transformations (Rose \& Miller, 1992, p. 178). As such, by exposing how the problem of usury has been articulated at various stages in Canadian history, we can begin to see the subtle changes in how this problem has been approached and the effects that they have had over time. As usury has become increasingly viewed as impacting on sovereign and rational financial consumers, for instance, its moral implications and the means by which we regulate it take on a markedly different character.

Secondly, this project intends to show how the practices of usury themselves from the floor plans of moneylenders to the advertising through which they attract their clientele - have served to constitute the position of usury within society in different ways at different times in history. This is more analogous to the work Foucault did in Discipline and Punish (1995) on spaces such as the plague town and the prison (p. 195203). By engaging with practices and the spaces in which usury occurs, one can gain insights into the changing assumptions that are being made about the clientele and the changing ways in which subjects on the margins of finance are constituted by the lender. This type of analysis will be done most explicitly in Chapter II, which compares the event of the payday loan with one of its historical analogues, pawnbroking.

Chapter III will focus specifically on the rise of what I see as one of the most important tools in governing the modern payday loan sector - financial literacy. Once again, it will not simply look at the history of this tool itself, but rather view its emergence within a longer history of government attempts to shape the economic 
imagination of its citizens. It will discuss the transformations that made a 'financial literacy' mandate possible, and the ways in which a financial literacy approach changes the terrain on which the problem of usury is approached. It will expose the liberal assumptions that are being made about the clients of the payday loan sector and the way in which financial literacy - as a means of knowing - obscures many of the structural economic issues that previous approaches highlighted. Finally, it will look at what is currently being done to contest this approach by community organizations and mainstream financial institutions.

Taken as a whole, this project seeks to expose the subtle discursive processes by which the previously deplored practices of usury have gained such a credible public image as an element of the mainstream financial industry. Furthermore, it shows that the current tools - discursive and legislative - through which we regulate and make sense of this realm obscure many of the economic and structural social divisions that were seen as paramount in previous eras. In doing so, the project highlights and lends credence to the work of non-governmental actors such as community organizations and credit unions which offer services that hinge on the longstanding discourses of thrift and social investment. Above all, though, the work seeks to elaborate the tremendous importance of knowledge - its formation, deployment and transformation - in guiding the course of historical change.

There are several concepts and themes which will emerge consistently throughout the following chapters. As such, it is perhaps useful to preface my analysis with a brief overview of how I am approaching some of these. Firstly, subjectivity: while the following analysis will make numerous claims regarding how subjects are constituted 
vis-à-vis various practices and discourses surrounding usury, this project does not seek to make any claims regarding the actual experience of borrowing or lending. Attempts to govern (whether they be through government programs, discourses or the actual spaces of lending) don't actually determine subjectivity, but rather are a component of an infinitely complex and overdetermined process of subject-formation. They "elicit, promote, facilitate, foster and attribute various capacities, qualities and statuses to particular agents," (Dean, 1999, p. 32) however they have no control over how those agents react or respond to this constitution. My project does not aim to narrate the actual experiences of usury, but rather highlight and expose the attempts that have been made to govern it. Another concept which will be drawn on throughout the analysis is that of moral economy. Because usury intersects so often historically with moral discourses, it is key to have a precise language by which we can discuss morality. The following thesis will not judge historical moments based on a transhistorical notion of moral good, but rather try to interrogate the forces - concepts, practices, discourses - that came together to underpin the moral economy of each moment. Fassin (2005) defines moral economy as "the economy of moral values and norms of a given group in a given moment" (p. 365). By emphasizing this relative moral aspect and its impacts on the usury question, one can both explicitly expose how normative judgments impact what is often presented as economic truth (Sayer, 2000), and gain some sense of the processes ('economic' and 'non-economic') wherein these claims to morality undergo transformation.

Thirdly, given that the following analysis relates to the regulation of an economic practice within one country, the state will figure heavily into the analysis. While there are many competing theories of how the state operates and the structures which constrain its 
actions, validating these will not directly be the aim of this thesis. To the extent to which I intend to engage with this question, it is with the modest claim that the state does not act as one unified totality under a static logic. Similarly, I hope to show that one cannot epocholize the state's approaches to problems, drawing concrete lines at points in history and claiming that firm and consistent ideological changes happened at these points. Rather, the diverse practices that the state engages in its attempts to govern are often contradictory, drawing on, transforming and reviving discourses and practices that long predate the practices themselves and in most cases don't reflect a unified, state-wide ideology. 


\section{Chapter 1: Debating Usury}

As stated in the introduction, the issue of usury has long been a contested topic of debate. For as long as money has been lent, there have been arguments over the legitimacy of the practice, the appropriate interest rate at which loans should be made, and the impact of this practice on those in financial distress. By looking at the ways in which payday lending is currently contested, and comparing that contestation to the way in which usury has been problematized in the past, one can gain insights into the position of the payday loan in modern society, and the conditions within which this practice has emerged as a modern 'financial service'. This chapter will not provide a social history of the payday loan, but rather begin to articulate a genealogical study thereof. It will show the presentation of the payday loan within modern usury discourses - as a relatively legitimate consumer practice - and shed light on the novelty of this constitution. It will examine the shifting logics under which usury has historically been contested within the Canadian context, and highlight some of the interesting changes in thought which have fostered the emergence of the payday loan. Primarily, this will be done through a rigorous examination of the Parliamentary and Senate debates that surrounded the passage of four pieces of legislation: The Money Lender's Act of 1906, the Small Loans Act of 1939, Section 349 of the Criminal Code in 1980 and Bill C-26, passed in 2006. Through this examination, the chapter seeks to expose the changing logic under which usury has been regulated, and in turn shed light on some of the conditions of possibility within which the payday loan industry has experienced its recent boom.

While previously, usury was contested as an immoral threat to a marginalized class of individuals who were understood as unable to protect themselves, today, the 
morality of small loans is no longer within the realm of contestation and the clientele is understood in a markedly different way. Rather than being constituted in discourse as a marginalized class as such, today the discourse surrounding payday loan regulation focuses on 'consumer protection' and thus assumes a rational and autonomous 'financial consumer' as the unit of analysis. In this new configuration, the goal of government action is to make what are seen as 'risky' populations less likely to execute unwise financial decisions. This becomes quite apparent when one examines the change in proposals within Parliament regarding the proactive role of the state in this realm. While previously reformers sought to have the state promote cooperative lending institutions among the poor and directly intervene in the lending market, today financial literacy programs are the primary avenue through which the state is understood to intervene.

There currently exists a wealth of literature debating the pragmatics of how to regulate usury law in Canada, however, engaging in this debate is not the aim of this project. While legal scholars such as Mary Anne Waldron (2003) and Jacob Ziegel (2003) have spent much of their careers analyzing the appropriate avenues through which the practices of usury ought to be monitored and regulated, this chapter is concerned more with the logic and forms of knowledge on which these types of debates depend. It is not primarily concerned with 'solving the problem' of usury, but rather "to rediscover at the root of these diverse solutions the general form of problematization that makes them possible" (Foucault \& Rabinow, 2006).

\section{Legislating Usury}

Given that this study adopts a post-structuralist approach to power and history, one might ask why the primary element in the analysis are those debates surrounding the 
legislation of usury. As Hunt \& Wickham (1994) have shown, Foucault himself did not see the law as the primary avenue through which power operates in a post-disciplinary society, but rather focused on the localized, capillary instances where power becomes visible (p. 56). As such, this analysis looks beyond the passage of legislation itself. It uses parliamentary discourse to highlight the way in which usury is socially understood and contested at different points in history. In this reading, legislation is seen as a reflection of societal norms; to the extent that it is concerned with the effects of legislation, it focuses on the effect that legal sanction can bring in further inscribing and consolidating these norms (see for example Foucault, 2007, p. 56; Dean, 2009, p. 141). By creating conditions in which legally sanctioned money lending businesses can operate with the high interest rates mentioned earlier, the law can serve to aid in the proliferation of usury practices, and thus foster the creation of a more favorable and legitimate image for moneylenders of this kind.

Let us turn then to the pieces of legislation with which this chapter will engage. The first piece of legislation included in the analysis is the Money Lender's Act, which was initially debated in the Senate in 1900 , then later debated and passed in the House of Commons in 1906 . The act specifically targeted loans under $\$ 500$, capping the interest rate at 12 percent per annum. The next significant piece of legislation with which the chapter will engage is the Small Loans Act, which was thoroughly debated and passed through the House of Commons in 1939. The Act sought to address the issue wherein lenders would hide their charges in lending fees and other costs which didn't technically qualify as 'interest'. Furthermore, it added targeted interest rate caps to loans up to $\$ 1500$. The third debate under examination is that surrounding the removal of these 
targeted interest rate restrictions for small loans. This was debated in the House of Commons first in 1976 as the unsuccessful Borrowers and Depositors Protection Act, then later in 1980 as Bill C-44, which repealed the Small Loans Act and amended the Criminal Code to universally cap interest rates at 60 percent annually. Finally, the paper will include analysis of the debates surrounding the passage of Bill C-26 in 2006 which exempted payday lenders from the Criminal Code interest rate cap, and devolved legislative responsibility in this sector to the provincial level.

\section{The Logic of Contestation}

Perhaps the most important element that one can analyze in the passage of these various pieces of legislation is the general logic under which the practices of usury are contested. By showing how usury is problematized at different points in history, one can illuminate the peculiarity of our current understanding of payday lending, as well as the vastly different discursive realms that usury has occupied within parliamentary discourse over the last century. As such, this is a good place to begin a discursive analysis of this sort.

In the initial debates on usury law, one of the most striking elements is the extent to which the logic of the credit market is contested. In numerous instances, the practice of high-interest, small lending is referred to as a "species of robbery" (Hon. Sir Mackenzie Bowell, May 8, 1900, Senate) and an enormous "evil" (Hon. J.L. Ilsley, April 25, 1939, House). One member of the House, Mr. J.A. March, even goes so far as to call those who are lending at high rates, "a vicious octopus that has been bleeding the industrial workers of our cities" (April 25, 1939). For the majority of the legislators who spoke in these initial debates, it was assumed that allowing the market for credit to operate according to 
its own internal logic is simply not an option. One member in the 1900 Senate debates, for instance, suggests that "no one should lend money at a higher rate than 12 percent" (Mr. Macdonald, May 14, 1900). The Hon. Sir Mackenzie Bowell of the Senate in 1900 forwards that capping the legal interest rate at even 20 percent per annum would "turn the legislation into ridicule" because it's simply an "unreasonable sum"; he suggests that letting the credit market operate unfettered is problematic because it assumes that "money is the same as any other commodity" (May 8, 1900). Similarly, Mr. Clarke, debating the Small Loans Act in 1939 in the House, suggests that legalizing a rate above 26.5 percent for small loans is wholly unadvisable as "it is only for the benefit of the loan companies" to have a rate that high (April 26, 1939).

When the logic of the market was advocated in these initial debates, members felt the need to state such as an explicitly political view. For instance, in the 1900 debate, one member of the Senate suggests that he is "a free trader in money as well as in other articles" and as such he does "not believe in interfering with the business of money lending" (Hon. Mr. Dever, May 14, 1900). This is also seen as recently as the 1974 House debates, wherein a member, Mr. Grafftey, suggests that the "free market is not necessarily the best mechanism for ensuring that interest rates are reasonable" (Nov. 1, 1974).

One can see a shift though in examining the most recent debates surrounding Bill C-26 which sought to exempt payday lenders from interest rate caps. No member in this set of debates felt the need to actually state their opinions regarding the way in which the credit market itself ought to operate. Rather than contesting the logic of the credit market, the majority of members understand the payday loan as a legitimate modern market 
service. "These small financial institutions that cater to the small user" one member argues, "are providing a valuable service to those people for what is a reasonable charge;" as such, they "are not criminals," but rather "providing a low level service for a relatively low amount of fees" (Mr. Ken Epp, Oct. 24, 2006). Similarly, Mr. Colin Carrie, suggests that payday lending ought to be exempt from regulation as it is important to allow Canadian consumers to "function in fair and efficient markets" (Oct. 24, 2006). It becomes clear from these statements that the market logic which was previously seen as problematic is now presented in more neutral, non-political terms. Within this logic, the payday loan industry becomes a "legitimate lending service" and as such "a knowledgeable consumer should be allowed to spend over 60 percent in interest if he or she wishes," as one member articulates (Mr. Derek Lee, Nov. 6, 2006). Even those who are critical of the practice of payday lending, such as Ms. Penny Priddy, suggest that surely "some are operating honourably," and that "no one says there should not be payday loan companies" (Nov. 6, 2006). In any case, any sweeping critique of the legitimacy of the free market in this sector is largely absent in contemporary discourse on the matter.

It is also interesting to note that with this legitimization of the market as a regulator of credit allocation, contestation of the morality of usury disappears from the discourse. For instance, in the initial 1900 debates surrounding usury law, members such as the Hon. Mr. Bernier explicitly stated that lending at 50 percent interest is in and of itself an "immoral" act (May 14, 1900, Senate) and in numerous instances in all debates prior to those in 1974 usury is referred to as an "evil". Similarly, a House member in 1939 suggested that "if a poor man has to pay anything like two percent a month, while a 
business man can secure his credit at a very much lower rate, there is something fundamentally wrong" (Mr. Woodsworth, April 25, 1939, emphasis added). However, these types of statements which question the morality of high interest lending become dramatically less frequent in both the debates of the 1970s, and those in 2006 .

\section{Articulating the Clientele}

Another important theme to examine in this type of analysis is the way in which the clients of usury are understood in legislative discourse. Given that the narrative portrayal of the subjects of usury - those impacted by legislation - surely shapes its problematization and thus the legislative reforms which are sought, this aspect of the discourse is quite important. The articulation of the subject's position is a crucial site which relates both to how usury's relationship to poverty is understood, as well as how the position of moneylenders within society is articulated. As such, transformations in this realm, whether subtle or dramatic, can have significant impacts on the form that contestation takes and the outcomes thereof.

In the Parliamentary and Senate discourse surrounding the passage of both the Money Lender's Act (1906) and the Small Loans Act (1939), perhaps the most striking element of the debates is the extent to which the clients of moneylenders are constituted as marginalized. For instance, The Money Lender's Act (1906) was initially proposed by the Hon. Mr. Mills for the purpose of protecting those "who are borrowing money under very needy circumstances at a very high rate of interest" (May 8, 1900, Senate). Mr. Blackmore, discussing the Small Loans Act (1939), cites the "significant fact" that "the people who borrow these small amount are already more or less poor" (April 25, 1939, House). This sentiment was shared in this debate by Mr. Slaght, who suggested the bill 
would help those "poor people who are in distress to the extent that they borrow money to carry on." Evidently, the practice of borrowing small amounts of money was explicitly constituted in this discourse as being something only done by those without alternate means.

Similarly, within both the 1906 and 1939 debates, the borrowers were often referred to as a "class" of individuals who were in need of protection from the state. The aforementioned Mr. Mills articulated that the Money Lender's Act was for the protection of "those whose pecuniary circumstances have become such that they are no longer able to protect themselves" (May 8, 1900, Senate). Mr. Mills furthermore suggested that the bill was to protect "the desperate class" (May 14, 1900, Senate), words that were shared by both Mr. Fitzpatrick and Mr. Osler in the House of Commons six years later (March $20,1906)$. By portraying the borrowers in this way - as a marginalized class of individuals who were unable to see to their own interests - the issue of usury was constituted as one wherein the state had an obligation to intervene on behalf of the less fortunate.

When one looks to the discourse surrounding the more recent pieces of legislation, a stark contrast begins to appear. Terms denoting poverty and desperation occur far less frequently in the debates, and, beginning in 1974, they are replaced with increasing frequency by more general terms such as those relating to 'the consumer'. For instance, in the 1974 debates, the disclosure legislation is presented as giving financial consumers more information to enable them to better navigate the marketplace. $\mathrm{Mr}$. Abbot, when presenting the legislation, suggests that it will "require a full, uniform and comprehensible disclosure system so that the consumer, before he enters into a deposit or 
borrowing transaction, will know all his rights and the obligations he will have to bear." (Nov. 1. 1974, House). Mr. Grafftey suggests that the most important thing is that government "ensure[s] that the individual consumer can do realistic comparative shopping from one institution to another." (Nov. 1, 1974, House). While this consumeroriented logic is contested by some in the House, it is clear that a transformation did occur in which it became possible to articulate usury as primarily an economic problem impacting rational, choice-making consumers.

Similarly, the uncontested truth claims which emerged in previous parliamentary discourse show up as hotly contested points of divergence in more recent times. The issue of compulsion on the part of the borrower to take on usurious loan rates, for instance, which was understood as fact earlier, now emerges as a point of disagreement. Mr. Peters and Mr. Philbrook, for instance, argue that borrowers are "usually very vulnerable people and are easily taken advantage of" and thus the government ought to protect them (Nov. 1, 1974, House). This is contrasted in 1976, with the Hon. Marcel Lamber, who states that "no one is compelled to borrow;" rather, he suggests, "those who borrow today perform a conscious act...they know that they have not got the money to buy what they want, so they borrow" (Nov. 3, 1976, House). This invocation of the rational consumer is shared by Mr. Andy Hogan, who states that the important thing for government to do is to "allow consumers the sovereignty that is supposed to be theirs under a market system" (Nov. 4, 1976, House). We can thus see that a subtle transformation occurred between the 1930s and the 1970s regarding how those affected by usury were constituted by those seeking to intervene upon it - while previously the subjects of usury were presented as unable to look after their own interests, they are given increasing degrees of consumer 
sovereignty within parliamentary discourse and the role of the state in their protection thus shifts to emphasize the proper functioning of the market. The subjects change from collective class subjects to individualized consumers which, while separate and autonomous remain universal in their rationality and relationship to the market.

\section{Articulating Possibilities for Broader State Intervention}

One other element of these debates that consistently arises is an acknowledgement that moneylending is occurring because a demand for it exists. As one member of the Senate articulated in 1906, the moneylenders "would not be able to succeed in their trade but for the fact that people want money and have no other means of getting it" (Mr. Bourassa, April 6, 1906). As such, outside of debating the appropriate rate at which money should be legally lent, there is much discussion on the part of legislators of other courses of action that the state could take to soften the impacts of this practice and/or reduce public demand for it. The subtle transformations in these proposed programs are quite illustrative of the significant changes respecting how we understand usury that have occurred over the last century.

A striking feature of the initial 1906 and 1939 debates is the advocacy of a broader form of state intervention wherein the demand for high interest lending is addressed through the promotion of other means of credit procurement. This is very much in keeping with the aforementioned point regarding how the clientele of moneylenders was understood as unable to protect themselves. For instance, Mr. W.F. MacLean, in the debates regarding the Money Lender's Act (1906), states that he is "convinced" that the encouragement of cooperative banks may be very useful in addressing the issue of high interest money lending (April 6, 1906, House). Similarly, numerous members of the 
House in the 1939 debates articulate a vision for the state to have a role in "educat[ing] the people along the lines of cooperative credit" (Mr. Tucker, April 25, 1939).

Those members who didn't push for a specifically educative role for the state did articulate a desire to insist that the 'legitimate' world of finance - chartered banks and credit unions - act to address the needs of small borrowers. For instance, members suggest that putting "some pressure" on the banking system and inducing these institutions "to fulfill their function...to serve the Canadian people" by broadening their operations to include small loans would go a long way in solving the issue of usury (Mr. McNiven, Mr. J.C. Landeryou, April 25, 1939). These suggestions are in keeping with the broad trend of state intervention that one can see in these early debates. One member, Mr. Blackmore, even goes so far in the 1939 debate to suggest that money be "created" to allow the government to enter into the small loans market; even if this solution doesn't come to fruition he states, then "certainly" the state "can support the banks" in engaging in the small loans business (April 25, 1939, House).

In the debates both in and following 1974, this advocacy of an active role for the state to address the demand for small loans is largely absent. Instead, it is replaced by a desire to foster a different sort of educative role for the state. Rather than seeing the state as potential promoter of different, cooperative understandings of the market vis-à-vis the credit union movement, these legislators sought to educate individual consumers about the operation of the financial market. For instance, Mr. Gafftey hopes in 1974 that "the provincial education systems will consider adding a compulsory personal money management course to their curricula" (Nov 1, 1974, House). Similarly, Mr. Huntington advocates a "very carefully designed educational program" to teach the public financial 
literacy, or what he terms "these very simple facts of life" (Nov. 1, 1974, House). Here, by placing financial literacy on the same terrain as sexual education, we can see that $\mathrm{Mr}$. Huntington presents this new realm of consumer knowledge as an important cornerstone of good citizenship - a set of fundamental skills that one needs to thrive in society. While previously there was a desire for the state to actively intervene in the credit market, or promote education which focused on solidarity among marginalized classes, this is evidently replaced in more recent debates by discourses surrounding the importance of 'financial literacy' and 'consumer' education.

\section{Liberal Governance and the Payday Lending 'Industry'}

How, then, are we to make sense of the discursive shifts that have been illustrated above? The analysis has shown that a number of changes have occurred - the subject of usury has been increasingly autonomized and given sovereignty as a consumer, the logic of the market as a rational entity has taken a prominent place, and the role of the state has shifted from being one of active intervention to that of education - but in what way does this change in knowledge reflect and promote the emergence of the payday loan as it is currently constituted? How have these transformations in how usury is problematized created the conditions in which what was previously seen as an immoral threat to a marginalized, powerless class has become a legitimate consumer service?

To answer this question, it is necessary to first examine the emergence of the 'financial consumer' as an object of discourse. Its arrival in these debates reflects a number of the transformations elaborated above and sheds light on what I see as a crucial shift in both how and under what logic the problem of usury is understood. As shown above, it was not until the debates of the 1970s that usury was presented through a 
primarily consumer lens. When the marginalized victim of usury emerges as a consumer in this way, the role of the state in regulating the practice takes on a markedly different character. Previously the state sought to protect the class of individuals impacted; it intimately knew their weaknesses, determined that they were unable to responsibly manage their own affairs and acted accordingly in protecting them not only from their own improvidence, but also from those who could potentially find incentive to profit off of the less-fortunate. The state related to this marginalized class 'pastorally' (see Foucault et al., 2003, p. 133, 189) insofar as it knew their individual and collective shortcomings and sought to protect their wellbeing. Today, however, the picture has shifted significantly; the state merely seeks to ensure that the 'consumer' is able to properly navigate the marketplace. In this change we can see that the subject of usury is given a degree of autonomy and sovereignty previously unafforded to it; these 'clients' are now understood as logical, "enterprising subjects" in du Gay's (1996) terminology. They are assumed to be acting in their own individual interests within a rational market.

This arrival of the 'financial consumer' within the discourse can also be understood as making possible a transformation in the specific techniques of governance employed by the state. When the focus is on ensuring that the consumer can act freely in the marketplace in this way, we can see that the individual subject, rather than the state, becomes the primary actor responsible for economic welfare. Instead of ensuring welfare, the state now seeks to allow free and autonomous individuals to pursue their own interests within the self-regulating market system. In order for these liberal subjects to be able to act freely, though, they must firstly be "shaped, guided and molded" so they are capable of exercising that freedom in the proper way (Dean, 1999, p. 165). Foucault, in 
his 1979 lectures on neo-liberal governmentality at the College de France, emphasized the importance of this shift toward the 'responsibilizing' role of the state and the emergence of these technologies of 'self-help'. As Lemke (2001) summarizes, these forms of government consist of developing "indirect techniques for leading and controlling individuals without at the same time being responsible for them" (p. 201). Thus, by rendering its subjects 'responsible' in this way, the problems of government, usury in this case, become those of 'self-care' rather than state intervention. The state is no longer responsible for the well-being of the citizens in the pastoral sense, but rather governs through the individual decisions of its citizens. As Langley (2007) articulates, by emphasizing the government of the self by the self, this approach "governs in and through...independent actions by promoting the very disciplinary technologies deemed necessary for a successful autonomous life" (p. 71).

On top of these effects, it is important to acknowledge how discursive shifts such as this become very material through their ability to shape how individuals make sense of their own experiences. While 'financial consumers', as articulated in the debates discussed above, didn't exist in any material sense prior to their discursive emergence, their discovery contributed to a shift in how people relate to their surroundings. As this conceptual framework was invented to make sense of economic subjects, people began to use it to make sense of their own relationship with the economy and thus the concept became 'real' in a very dynamic fashion (see Hacking, 2004, p. 106). As this way of knowing began to permeate both the macro, policy-level discourse and the experience of economic subjects, the process began wherein something that previously didn't existthe financial consumer - became a major factor in the governance of this realm. 
We can gain further insights into these changes by looking at transformations regarding the role of the state within the discourse articulated above. While previously, legislators argued that the state should take the role of promoting credit unions or intervening upon the economy in the name of social welfare by forcing banks to lend to risky borrowers, this was largely replaced in the 1970s by arguments for what is today termed 'financial literacy' education. By arming 'financial consumers' with the information and tools necessary to navigate the complicated world of finance, responsibility for the ills associated with usury shifts from the state to the empowered individual. Today, we can see the institutional home of this form of governance in the Financial Consumer Agency of Canada (FCAC), which was launched in 2001 with the slogan "empowering consumers;" its explicit aim is giving financial consumers the tools to navigate the marketplace (FCAC, 2010). Interestingly, we have recently witnessed a shift toward targeting youth in this type of programming; both British Columbia and Ontario's provincial governments have recently integrated financial literacy programming into their high school curricula, for instance (FAIR Canada, 2009). As well, the FCAC has developed a program entitled "The Money Belt" wherein youth are directly targeting by financial literacy programming; it seeks to help young consumers "make informed decisions and avoid high levels of debt," and will be discussed in greater detail in Chapter Three of this study (Money Belt, 2010, emphasis added). Thus, we can see that with the rise of financial literacy as a technology of governance, the tools necessary to manage ones financial affairs are increasingly being understood as an essential life skill. The empowered and sovereign consumer is invoked through these technologies and given responsibility over his or her financial wellbeing. At the same 
time that this transformation happens, the role of the state takes on a different character; it is no longer in a position to encroach on the rights and freedoms of the consumer, but rather just "promot[es] particular forms of the conduct of life" vis-à-vis technologies of empowerment such as financial literacy (Dean, 1992, p. 218). Specific technologies are developed within this realm of 'financial literacy' such as risk-reward calculations, budgeting techniques and the 'skillful' use of credit, and the state takes on the role of teaching and inscribing them firmly into the popular imagination.

Outside of the shifting modes of governance that have been reflected in this analysis, it is also interesting to note changes in the logic by which the practices of usury have been contested. As was shown in the parliamentary discourse, the practices of usury were previously understood as immoral in their own right. The unfettered functioning of the credit market was seen as a threat to a marginalized class of individuals, and reforms were put in place to directly constrain the market in the protection of this group. By 1980 , though, this state of affairs had shifted and instead of targeting legislation to protect only borrowers of small sums, lending rates were capped at 60 percent per annum for all sizes of personal loans. Further, by 2006, legislators successfully sought to exempt the payday lender from this universal interest rate and devolve responsibility for this type of loan to the provinces.

What is perhaps most striking about these changes is the shifting realm within which this problem is generally understood. While previously usury was understood primarily as a 'social' issue - a threat to the well-being of 'society' - today the logic under which it is contested is primarily economic. Scholars such as Donzelot (1979, 1988) have written much about the way in which concern over 'the social' impacted the 
methods by which governance occurred historically. This is not to suggest that legislators sought to manage society through state intervention, but rather the logic of a certain 'social' wellbeing shaped the conditions within which reform was sought. As Rose (1996) has suggested, this concern for 'the social' "set the terms for the way in which human intellectual, political and moral authorities....thought about and acted upon their collective experience" (p. 329). By conceiving of usury as a threat to the wellbeing of 'society' in this way, legislators in the early debates were able to bring forward legislation which sought outright to curb the practices vis-à-vis targeted interest rate caps and demand management.

However, when we examine the debates in and following the 1970s, it becomes clear that this focus on the wellbeing of 'society' has less resonance. Instead, certain forms of usury seem to have been reconstituted into an issue of finance - placed within a privileged realm of economics which is thought to operate under its own internal logic. Instead of the practice of lending money at exorbitant rates being the problem, focus is shifted to the practices associated with usury - the coercive methods of the loan shark, for instance. When The Small Loans Act of 1980, which transformed usurious lending into a strictly criminal offense, was being debated, for example, it was advocated on the grounds that it would better equip the state to prosecute loan sharks. Similarly, when payday loans were exempted from this criminal rate of interest with the passage of Bill C-26, it was rationalized on the grounds that payday lending was distinct from this criminal activity. "This does not mean that loan sharks will have a field day," one member states, "This means that genuine lending businesses, which I described as payday 
loan operations, can carry on with their legitimate lending services... without fear that their practices will offend the criminal law" (Mr. Derek Lee, November 6, 2006, House).

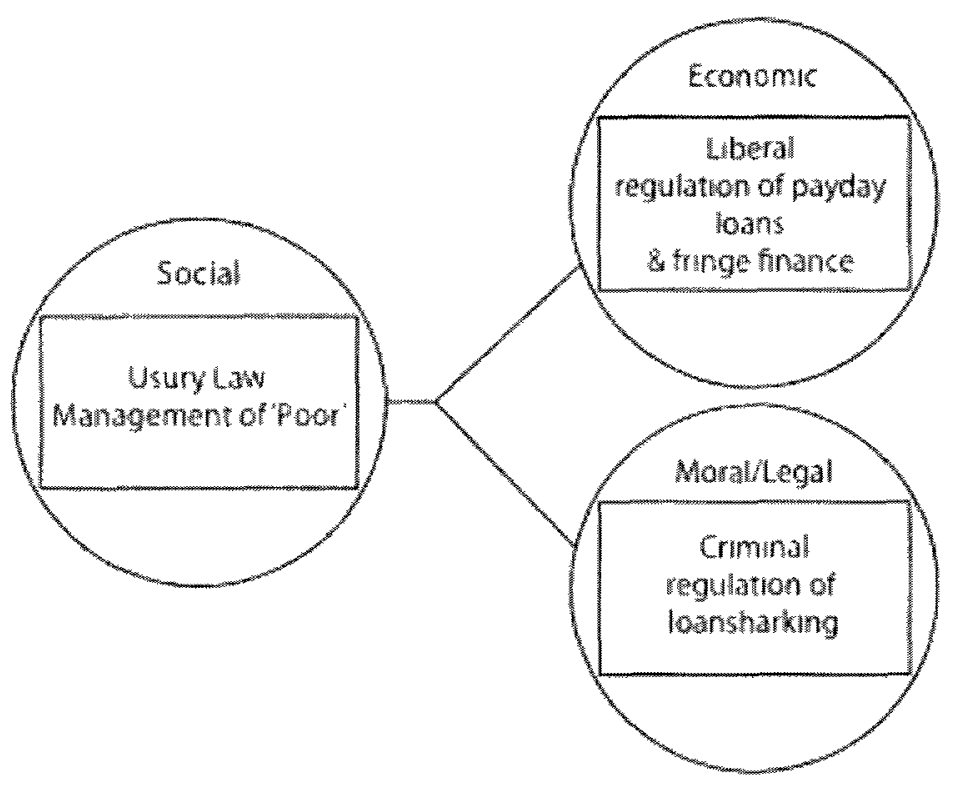

Figure 1: Transformation of the Social

As long as high interest lending is occurring within the public and legitimate world of 'finance', it is no longer understood as problematic in its own right. One can see this transformation most acutely in the number of times wherein payday lending is referred to as a part of the 'financial industry' in the 2006 debates; it is primarily presented in this realm as an 'economic' rather than 'social' issue and contested within the logical parameters therein. Thus, it becomes clear that when problems are understood as economic, legislators "no longer conceive of themselves as operating upon a naturally functioning and systematically integrated national population whose 'social' coherence is a condition for its economic security" (Rose, 1996, p. 330). Instead, it is assumed that "in economics and finance there exists a prepolitical domain of material economic reality," 
(de Goede, 2005, p. 7) and thus the role of legislator is simply to ensure its smooth functioning.

\section{Conclusion}

This chapter has sought to highlight some important discursive shifts that have helped create the conditions of possibility within which the payday loan industry has emerged as a relatively legitimate entity. It has by no means offered a conclusive genealogy of usury in Canada, but merely shed light on the changing logic under which this issue has been politically contested over the last century of Canadian history. Surely, there are other elements which contributed to the emergence of the payday loan as an acceptable practice which deserve further analysis. For instance, it was largely out of a concern for the extremely high interest rates of the late 1970s that legislators removed the targeted interest rate caps present in the Small Loans Act. During that period, 'legitimate' lending institutions such as credit unions, which were regulated by the Act, were not able to lend at a profitable rate due to the macro-economic conditions which spawned high inflation. In 1979, for example, the prime lending rate in Canada was 12.90 percent, which effectively made it impossible to offer loans of under $\$ 1500$ due to the 12 percent cap of the Small Loans Act.

Evidently, there were a myriad of both material and ideational shifts going on during this period which came together to create the conditions for the payday loan to emerge and as such, this chapter serves as but a limited interrogation of one aspect thereof. However, this isn't to suggest that the shifts that this paper has highlighted are without effect. Surely, how we conceive of the problem of usury - who it effects, what it threatens, the logic under which it operates - has implications for how we seek to manage 
it. By highlighting the discursive shifts that have occurred in both the Parliament and Senate on this topic, this chapter has sought to make this point clear. Were it not for the transformations that have occurred in our thinking about usury, the payday loan would not be understood in the way it is today; its existence as a legitimate consumer service is dependent on and serves to reinforce changes in how we think about finance, subjects of usury, and the role of the state more broadly. 


\section{Chapter 2: The Event of Borrowing}

While the discursive elements discussed in the previous chapter are a crucial step in elucidating how the problem of usury has changed over time, the language surrounding an issue such as this, while performative in important ways, cannot tell the entire story of how a problem as broad as this is governed. Given that the actual practice of fringe banking - its events, spaces, locales and general flavour - serve to shape the image and points of reference that we use to make sense of this problem, noting changes in these very practical details can be incredibly illuminating in understanding the subtle processes of change that this study is trying to highlight.

As such, this chapter will focus primarily on the specific practices that have characterized the fringe banking sector at different points in history. By rigorously examining two sets of practices, or 'events' - pawnbroking and payday lending - both of which fall under the contemporary heading of 'fringe finance', one can gain a richer understanding of the diverse technologies of power that have characterized the sector at different points in history. This analysis is not done in an attempt to periodize history, drawing a line between an era of pawnbroking and an era of payday lending. Evidently, these practices have coincided and overlapped in recent decades. Rather, the chapter uses these two events as exemplars to highlight the novelty of the understanding of usury that has come with the rise of payday lending as a widespread phenomenon. Given that there are notable similarities between the practices - they both offer a high priced form of short term relief to populations who are unable or unwilling to access credit through traditional financial institutions - comparing their character can highlight interesting changes that are taking place in how we understand and make sense of the issues surrounding high- 
interest lending.

Primarily, this chapter seeks to highlight the extent to which the current dominance of payday lending within fringe finance brings with it a very contingent understanding of the marginalized financial subject and the role that credit plays in the lives of the poor. Particular attention will be paid to the contrasting representations of the subjects of usury that have been invoked from the diverse sets of practices that have existed within this sector at different points in time. More broadly, the chapter seeks to lend credence to Aitken's (2006) assertion that one cannot rely solely on the conceptualization of the autonomous, rational, risk-managing subject that one sees in much of the financialization literature $^{2}$ to understand the subjects of the fringe finance sector (p. 486). While the payday loan is initially presented in a liberal, consumerist light, the illiberal side of this story quickly emerges in the event that one is unable to repay the loan. As such, conceptualizing the debtor as the 'neoliberal', somewhat emancipated agent is not useful in understanding all aspects of modern finance.

The chapter begins by briefly outlining the respective histories of the pawnbroking and payday lending industries. Within that section, particular attention will be paid to the size, practices and structure of the industries in an attempt to provide a context for the later discussion. After this, I will interrogate these industries' economic, moral and geographical positions vis-à-vis their clientele in an attempt to elucidate an appreciation for the relationship that the lender has with the borrower in each instance. Following this discussion, the paper will focus on the way in which the borrower is constituted in various ways under each set of practices: firstly, it will look at how the advertising of

${ }^{2}$ See, for instance, Harmes (2001) and Langley (2008). 
each industry represents the poor in different ways; secondly, how the organization of the practice of lending itself suggests quite different things about the borrower in each case; and finally how the collections practices of each regime shed light on some of the coercive practices often left unexplored in governmentality literature.

\section{Pawnbrokers: An Age Old Lender of Last Resort}

Over the course of the long history of pawnbroking, the organization of the transaction itself has undergone little modification. Typically, a borrower brings their physical collateral to the lender and gives it to them in exchange for a loan. The lender then holds the collateral for a fixed period of time waiting for the borrower to repay the loan. If at the end of that period, the loan (which usually amounts to substantially less than the value of the collateral) plus interest and fees are not repaid, the lender legally takes possession of the collateral and the debt is extinguished.

This practice has existed in various forms since ancient times. One can find numerous references to pawning in the Old Testament (see, for instance, Exodus Chapter 22), yet evidence suggests that even prior to that, in ancient China, the earliest practices of what would now be called pawnbroking occurred (Whelan, 1979, p. 1). In Europe, some of the earliest pawnshops were run by charitable organizations, explicitly stating that they existed as a service to the poor. The monti di pieta, or "banks that take pity" were created to combat the usurious rates charged by other moneylenders at the time (Caskey, 1994, p. 13). After 1784, the British government began to explicitly regulate the pawn industry by setting ceilings on the interest rates charged by lenders.

In the United States as well, pawnbroking has a formidable history. Famous brokers such as John S. Sommer operated in New York City as early as the 1650s (Woloson, 
2007, p. 41; Caskey, 1994, p. 16). The industry expanded in America throughout the nineteenth century, growing steadily until 1930 , when it entered a period of sharp contraction (Caskey, 1994, p. 28). This decline in the industry's size continued until the late 1970 s, then throughout the 1980 s and early 1990 s, the industry began to once again grow rapidly (Caskey \& Zikmund, 1990, p. 8). However, in the late 1990s, the number of pawnshops in America began to once again decline with the emergence of alternative forms of low-income consumer credit, a trend that has continued through to the present (Caskey, 2005, p. 26).

In Canada, it is extremely difficult to find accurate statistics reflecting the exact number of pawnbrokers and how it changes over time. This is due to the fact that pawnbroking is generally regulated at the municipal level and there isn't a coherent national database of brokers.

\section{Payday Lenders: The Most Recent Addition to the Consumer Financial Landscape}

The practice that we currently refer to as payday lending has a long and tumultuous history. This practice - wherein money is lent against one's salary - finds its antecedents in the early $20^{\text {th }}$ century, when loan sharks disguised their practice as a "wage assignment' in an effort to avoid usury legislation. As early as the 1920s, high interest lenders began "purchasing" the salaries of wage earners at a discount few days before payday (Nugent, 1941, p. 5, 10); because they weren't actually lending money, but rather purchasing earnings, they would often avoid compliance with interest rate caps. In the mid-1990s, the payday loan industry emerged and began to grow rapidly. By 1999 , estimates suggest that there were roughly 10,000 payday lending outlets in the United States (Elliehausen \& Lawrence, 2001) and by 2008 this number is said to have grown to 
over 22,000 (Brook, 2009, p. 43). Today, there are over $\$ 45$ billion in loans given through the payday lending industry in the United States annually (Prager, 2009, p. 8).

\section{Positioning Fringe Finance}

\section{Economically}

As a point of departure into the analysis, it is useful to interrogate the economic role that each of these practices has played in modern society. The economic relationship that both the pawnbroking and payday lending industries have with their customers and finance as a whole highlights not only the threads of continuity between the two practices, but also the subtle ways in which the landscape of fringe finance is currently undergoing transformations.

The practice of pawnbroking, by virtue of its easily accessible nature and its limited requirements in terms of credit and financial history, tended to cater to individuals on the margins of the financial sector. Its long boom in early America has been attributed to the paucity among new migrants of the social and economic ties that would allow them to borrow small sums of money from someone they knew personally. Woloson, (2007) writes that during this period,

Pawning served as a strategy for coping with crisis, and the pawn-broker became as essential to many workers' economic lives as their wages. Not only did people find fewer and lower-paying opportunities in the cities of antebellum America, but they had also been removed from the socioeconomic ties of smaller communities. (p. 55)

Thus, the relationship between the broker and the client was that of dependence in many ways. For many working class families, it was almost a weekly routine (Caskey, 1994, p. 18). Without the alternate option of borrowing from someone with whom one had a personal relationship, they were forced in difficult times to engage in a transaction 
with their local pawnbroker. Given the widespread financial instability during this period it is not surprising that brokers were so successful. As a primary safety net for many wage earners during this period (Woloson, 2007, p. 53, 56), we can see the pawnbroker as one piece of a broad, non-universal network of localized services which enabled people to cope with economic downfall and uncertainty.

When one looks at pawnbroking in more recent history, it becomes clear that this relationship between the broker and those on the economic margins has not fundamentally changed. Typically, the client of the pawnbroker earns a low or moderate income (Johnson \& Johnson, 1998), and is using the service either to get money for a "family or personal emergency" or to "pay or consolidate bills" (Caskey 1994, p. 70). In a 1989 interview with the New York Times, Jack Daugherty, a pawnshop owner, candidly explained where his clientele come from; "I could take my customers and put them on a bus and drive them down to a bank and the bank would laugh at them," he said, "That's why they're my customers" (Kleinfield, 1989).

Comparing this relationship to that which exists between the payday lender and the clientele illustrates much continuity. In one of the largest studies of customer demand in the industry, Elliehausen \& Lawrence (2001) showed that nearly three quarters of customers surveyed had been turned down by a creditor or not given as much credit as they had applied for within the five years prior to their transaction; furthermore, two thirds of customers surveyed had thought about applying for credit elsewhere, but changed their minds because they presumed they would be turned down (p, 46). While pawnbroking and payday lending tend to find much of their client base in low-income demographics lacking alternative credit options, there are noteworthy 
differences in their clientele. For instance, unlike in pawnbroking, to get a payday loan one needs to have a steady stream of income (whether it be from employment, social assistance, or employment insurance) and a bank account. This account requirement puts the industry in direct contact with the mainstream financial world, whereas previously, pawnbroking was a separate, distinct entity. Aitken (2006) has elaborated that beyond this account requirement, payday lending networks "often rely on a range of long-term contractual and commercial relationships with mainstream deposit institutions in order to help process payments, access client accounts and, often, evade regulatory restrictions or interest limitations" (p. 280). As such, with the transformation of fringe finance into a sector heavily dominated by payday lending, low-income borrowers are now situated in much closer proximity to the world of mainstream finance and all of the legitimacy that society affords to it.

\section{Societally}

Examining how these different types of lenders have been understood within their social context is important for the purposes of this analysis, and can draw attention to the ways in which these industries have been constituted and problematized. While this chapter was referred to as an analysis of 'fringe-finance', it is important to state that pawnbroking, as understood by those interested in regulating it as a practice, has not historically been constituted as a 'financial' transaction. ${ }^{3}$ While brokers have always extended credit to their clientele, it was those parties interested primarily in protecting the

\footnotetext{
${ }^{3}$ This is exemplified by the fact that there are no national level statistics regarding the scope or magnitude of the pawning industry like one would find for a mainstream element of the financial world. Instead, regulation over pawnbrokers is largely dependent on municipal bylaws.
} 
'welfare' of society, rather than the regulation of 'finance' who have historically been most concerned with the practice. For instance, in the early 1800 s, an annual report of New York City's Society for the Prevention of Pauperism sternly criticized the industry for its role in the creation of poverty; similarly the Pennsylvania Society for the Promotion of Public Economy referred to the growth of the practice as "a most serious and growing evil" (Woloson, 2007, p. 45). It was not primarily understood within the context of its economic regulation, but rather as a threat to social wellbeing. Much in the same way that the usury debates discussed in the previous chapter condemned high interest lending as fundamentally problematic, pawn broking has historically been constituted by its social reformer critics as a dubious and seedy practice which ought to be stated as such.

Payday lending, on the other hand, is primarily understood as an economic transaction between autonomous rational agents, and thus regulated as such. Attention is paid by regulators and advocates to the interest rates charged and the regulation surrounding the ability to 'roll-over' a loan. It is regulated as a marginal element within the larger financial world which, as articulated earlier, it has close ties to. Though it is still condemned by critics as 'predatory', its impacts on society are primarily understood and regulated through the discourses of finance. Since the devolution of payday loan regulation to the provincial level in 2006 , a number of jurisdictions have passed legislation specifically regulating the amount which lenders are allowed to charge. British Columbia, Alberta and Saskatchewan have capped loans at $\$ 23$ per $\$ 100$ (Government of British Columbia, 2009; Government of Alberta, 2009; Government of Saskatchewan, 2010), Ontario has passed a law limiting interest to $\$ 21$ per $\$ 100$ loan (Government of 
Ontario, 2010), and Manitoba has gone even further still to cap these short term loans at $\$ 17$ per $\$ 100$ (Government of Manitoba, 2010). Other provinces have acknowledged payday lending as a legitimate financial transaction yet refrained from officially regulating interest rates. Newfoundland and Labrador, for instance, has passed laws forcing all lenders to register with the province, yet has refrained from actually capping interest rates (National Union of Public and General Employees, 2010, p. 6). Similarly, Nova Scotia has taken the step of mandating registration of lenders and prohibiting rollovers, yet has devolved the regulation of the interest rate to its public utility board, which currently allows rates up to $\$ 25$ per $\$ 100$ loan (Government of Nova Scotia, 2011).

\section{Geographically}

The geography of fringe financial institutions such as these can serve to illuminate further the relationship that they have both with their clientele and with the world of finance generally. The location of pawnbrokers, for instance, has historically been very reflective of the type of clientele which they attempt to attract. Brokers have historically been located either in or very close to those low-income neighbourhoods where their clientele reside. For instance, New York brokers tended to locate their shops on Chatham Street in the early 19 th century, a rather seedy area known for its saloons and brothels during that period. In Philadelphia, brokers tended to congregate in the North and South of the city, away from the bourgeois retail sector which surrounded High Street (Woloson, 2007, p. 57). Similarly, in Canada, one can still today find a major concentration of brokers on Church Street in Toronto, just adjacent to Cabbagetown and Corktown. These historically working class neighbourhoods found their names in the major influx of Irish immigrants that flooded the city and acted as labourers in the latter 
half of the $19^{\text {th }}$ century.

The reasons for this geographic concentration shed much light on pawnbroking itself. Since the industry depends heavily on the business of those on the margins of society, yet its clients need to physically transport their goods to the broker in exchange for the loan, it makes sense that the broker ought to be close to their clients; transportation costs relative to loan sizes can be substantial if the borrower is looking to pawn something quite large. However, this is not the only reason for the concentration of brokers in less visible areas of the community. Historically, the practice of pawnbroking has been painted it in a rather dubious light; it is seen as a place where those in financial desperation turn for a lender of last resort. As such, when those of higher classes resorted to the broker for credit, it was often not something they wanted to be publicly known. De Roover (1948), writing of pawnbroker locations in Bruges, Belgium comments that the lenders sought locations in remote areas so that "customers could find their way to the pawnshop without being recognized" (p. 113).

When one compares this geography and the reasons for it to that of payday lending, a contrast begins to emerge. While concentrations of payday lending outlets can indeed be found in racialized, low-income neighbourhoods (see, for instance, Prager, 2009), they are also quite visible in places where pawnbrokers would not have been seen historically: financial districts and commercial/retail areas. For instance, a cursory analysis of the geography of payday lenders in Ottawa, Ontario shows a heavy concentration of outlets on Bank Street between Somerset and Laurier, an area in close proximity to a high concentration of financial institutions and government offices. Similarly, in Toronto, Ontario, there are eighteen payday lending outlets located on Yonge Street between King 
(Toronto's financial district) and Bloor (a high-end retail area) (Whitelaw, 2008). Ironically, there is even a payday loan outlet (Cash Money) in the same building as the Government of Canada's Department of Finance. Evidently, engagement with the fringe finance sector carries a different meaning today than it has historically. It has been brought out of the margins and into the public sphere, where it can be observed as 'normal' behaviour among consumers.

Rather than indicating that the consumer friendly and public payday loan sector has simply replaced pawnbroking and brought fringe finance into this more observable realm, this is a reflection of both changes in modern urban geography and the position of these types of institutions socially. While previously, it would have been unthinkable to have a pawnshop in a space as public at the Department of Finance building, today the fringe finance service of payday lending is serving to challenge the borders of illegitimacy that have bounded these services in the past. This can be seen in both the presentation of the service itself (discussed later in this chapter) and the business alliances that many payday lenders have engaged in that present their product in a less dubious light. For instance, both Money Mart and Cash Money, two of the Canada's largest national payday lending chains, offer Western Union money transfer services in their locations. By creating avenues through which individuals have the option of entering their stores for reasons which don't indicate financial desperation, these chains have made their services available to those who would normally be embarrassed or shy to be seen publically entering a fringe financial retailer. These changes are occurring at the same time as processes of gentrification have brought previously depressed neighbourhoods such as those mentioned above into the sphere of public commerce, and thus made both urban 
poverty and pawnbrokers much more visible than was previously the case.

This geography is further complicated when one considers the recent increase in the number of online payday loan outlets, which often have no physical retail location. By operating online, these lenders are able to avoid the strict regulatory environments which may exist in certain jurisdictions. Websites like Easy Online Payday Loans (2009) and CashNet USA (2009), which operate in the jurisdictions of Arizona and Illinois, respectively, both publish explicitly on their websites that they are bound by their jurisdiction's state laws only, despite the fact that they lend across the United States. There are even cases of online lenders operating off of tribal Indian lands in the US to completely avoid state-level legislation (Fogarty, 2011). Similarly in Canada, organizations like Mr. Payday offer loans through their website which states that "all aspects and transactions on this site will be deemed to have taken place in our office in the province of British Columbia, regardless of where you may be accessing this site" (Mr. Payday, 2011). This is quite a different state of affairs than that of the pawnbroker, which was geographically situated in the low-income community where it did business, and expected to follow the regulations therein. This contrast is further elucidated if one looks to other forms of regulation that shape the conduct of this sector.

\section{Morally}

Understanding the forms of regulation which have historically shaped the conduct of fringe lenders can shed much light on the novelty of the current configuration of the sector. Currently, under the payday lending regime, the transaction between the borrower and the lender is primarily an economic one, guided by calculative economic logic. The amount of the loan given, the degree of interest and fees which accompany it, and even 
who is awarded a loan are all explicitly contingent upon the borrower's recent bank transaction history, their bi-weekly pay, and their employment history. In fact, this is the only information that the typical payday lender will require that you bring when asking for a loan. These factors are all verified by the lender (albeit without a credit check) and the loan is awarded thereafter, with no attention given to the reason for the loan, nor the character of the individual seeking it. This is exemplified by the fact that with some large payday lending firms, employees are expected to follow a script in their dealings with customers. Money Mart, for instance, has all their employees use the exact same phrases when signing people up for loans and offers a bonus structure which is partially based on the extent to which this script is followed (Former Money Mart employee, personal communication, Oct. 31, 2010). In short, this results in the interaction between the lender and borrower being far more standardized ${ }^{4}$ and formal in the payday lending regime. The person granting the loan, who is typically a waged employee of the payday firm, is not at all concerned with the specificities of the individual borrower, but rather relies on the calculative technologies established by their employer in assessing an individual's creditworthiness.

When this is contrasted with the configuration of the regulatory principles under pawnbroking, it becomes clear that the technologies employed were more grounded in the community. There is much evidence suggesting that the broker was firmly situated

\footnotetext{
${ }^{4}$ One specific example of this standardization is in the greeting that Money Mart employees are expected to use when customers have finished their transactions. If the customer is a wage earner, the employee is expected to say "see you in two weeks" as the customer leaves the store. If, however, the customer is a recipient of social assistance, which is issued on a monthly basis, the employee says "see you next month." One former employee (personal communication, Oct. 31, 2010) recalled that after having said "see you next time" to a customer, they were reprimanded by their superior on the grounds that they didn't follow the script.
} 
within the social relations in which he dealt and not driven by an exclusively rational/economic logic in determining the extent to which credit would be awarded.

For evidence of this trend, one can look to the way in which brokers themselves describe both their profession and their clientele. In the late 1820 s and early 1830 s, a journalist who wrote as "The Night Hawk" toured Philadelphia's oyster cellars, saloons and other seedy sites of working class disrepute, writing of his experiences in a weekly column for the Mechanic's Free Press. Two such articles deal with pawnbrokers, describing the type of connections they have with their clientele and the way in which they are situated within their communities. For instance, the Night Hawk quotes the broker as describing one client in the following way:

That poor unfortunate woman, was and is in point of nature, the daughter of rich parents. She married a profligate, and was disowned; extravagance and dissipation, gradually brought on poverty, and this poor woman now struggles with three small children, and a besotted husband through the world. (Night Hawk, Mechanics Free Press, July 4, 1829)

From this passage one can see that the broker displays true empathy for the client's plight; he, having bought a set of silver spoons from her, seems genuinely concerned with the events which lead up to her requesting his services. This is not to say that his sympathy for the client was the only determinant of the level of credit extended, but rather that the connection between the lender and the borrower is more likely to be impacted by technologies of regulation outside of calculative economic principles than is the case under the payday lending regime.

This connection between the borrower and the pawnbroker is exemplified in the contemporary setting beautifully in a recent TVO documentary, Broke (Dransford, 2009), which follows the experiences of one Edmonton pawnbroker, David Woolfson, and 
serves to highlight the close relationships he has with many of his clientele. In one scene a woman, Dorothy, who is a regular of his shop enters to pawn some goods. She explains to the filmmakers how she and Mr. Woolfson have set up a limit, $\$ 400-\$ 500$, which is the maximum amount of money she's allowed to have borrowed at one time. Mr. Woolfson explains once she's left the store:

She's just a compulsive spender. She's not a drug addict, she's not a drinker, she's not smoker, she's just a compulsive spender. You give her ten bucks that'll last her a day, she'll spend ten bucks, you give her a hundred bucks, that'll only last her a day, she'll spend it. That's Dorothy. So I restrict what I give her. (Dransford, 2009)

This is further demonstrated when one considers the fact that as early as the beginning of the 1800 s, pawnbrokers in New York City had to procure a license from the Mayor which would attest to the applicant's "good character," a trend which has carried on until today (Woloson, 2007, p. 43). Given the nature of pawnbroking, wherein both the value of the goods pawned and the credibility of the client are both determined wholly by the individual broker, it is perhaps not surprising that regulators assume the broker needs to have an acceptable moral compass to guide their actions. However, this trend still speaks to the fact that the decision of creditworthiness and the degree of interest charged were regulated by quite different technologies under the pawnbroking regime.

One can find more contemporary evidence of this trend, as well. In a New York Times article entitled 'Running the Little Man's Bank' (1989), the journalist describes an interaction between a broker, Dwight Nash, and a desperate customer:

A young tidily dressed woman came in to plead for mercy. Her loan was a week overdue. She had borrowed $\$ 250$ on a VCR, color TV and camera. Her brother was in jail and the money managed to spring him. "I need just a couple more weeks," she said. "I want my stuff. I've been 
working like a big dog to get it out." "Legally, you know, it's mine," Mr. Nash said. "But I don't want your stuff. So we'll let it ride." As she left, Mr. Nash was pensive for a moment. "She'll be back," he said. "I feel it in my gut. I want her money, not her stuff." (Kleinfield, 1989)

The individual discretion that the broker has over the contract between himself and the client places the transaction within the social relations that exist between the two individuals, rather than it being defined primarily by economic logic as payday lending is today. One can consider the fact that the broker has typically been referred to as 'uncle' a moniker which denotes an intimate familial tie - to better understand this relationship. Speaking of his business, Mr. Nash, the broker cited above, remarked that,

We've built it up by treating people like they're human beings. Most people who come, they're already mad that they have to be here. If you comfort them and talk to them, you calm them down. You have to use some psychology in this business. (Kleinfield, 1989).

Another broker states that he "asks all [his] managers before [he] employs them if they've ever been broke." If not, they're not offered jobs (Management Today, 1991). These quotes serve to illustrate that for a pawnbroker to be successful, they have historically needed to have a keen understanding of their clients and the community in which they operate. This is a fundamentally different borrower-lender relationship than that which exists today under payday lending.

\section{Constituting the Subject}

While the above analysis regarding the position of the lender vis-à-vis the borrower under each of these lending regimes can shed light on the various methods by which the practices of fringe-lending themselves have changed dramatically with the advent of payday lending, to fully understand how this change affects the governance of the subjects of fringe finance and our thinking about poverty one needs to engage with the 
constitution of the individual borrower. How is it, for instance, that the borrower comes to be imagined and understood in payday lending, and how is this different than under the previous regime? What type of subject is assumed by the lender in each instance? To answer these types of questions, one can look to both the characteristics of the lending transaction itself and the way in which lenders have attracted their clientele at different periods in history.

\section{Constitution through Advertising}

It is not very difficult to identify the ways in which payday lenders try to attract their customers; their attempts tend to be quite visible. Typically, the outlets themselves have large, well-lit signage depicting the name of the company. As well, there is a wealth of literature within the outlets, which provide information regarding the requirements for a loan, why seeking a payday loan is a prudent decision, and how payday loans work. Furthermore, many firms use television advertisements to attract clients, typically by showing how fast and convenient their services are.

After surveying these various forms of advertising, it becomes clear that there is an overwhelming focus on 'convenience' and what can broadly be framed as 'legitimacy'.

For example, a copy of the text within a pamphlet published by Cash Money states that:

Our many convenient services are here to make your life easier. And once you discover our friendly service and all our convenient locations (open when the banks aren't), you'll see why Cash Money is the place more and more people are turning to for their cash. Right now! (Cash Money, 2009)

From this one can infer that the lender is presuming that the borrower is a rational consumer whose choices are informed by the extent to which one service is more convenient than another. Similarly, in the Money Mart pamphlet shown below, the 
primary message is that this service is a modern convenience which will make one's life easier. No longer will you be constrained by the inconvenience of bank hours, nor the scrutiny of credit checks; with payday lending you are able to get your money very quickly and on your schedule.

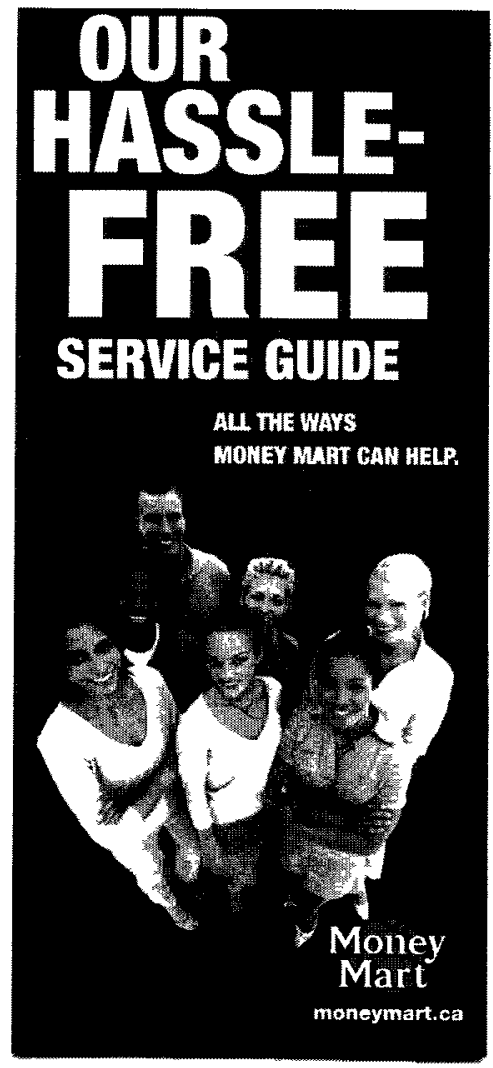

Figure 2: Money Mart Brochure. (2009). Source: Money Mart, Ottawa, Ontario. What is perhaps most striking about this is the way in which the 'consumer' is represented. By framing the choice to use payday lending services as a mere modern convenience, the extent to which the user is driven by desperation is completely hidden. Look, for instance, at the photos of the individuals on the pamphlet. They are represented as happy, seemingly middle class workers. Similar advertisements often show nurses, firefighters, policemen, and parents. This effort on part of the firms to normalize the practice by showing 'everyday' users serves to overshadow the reality that the majority 
of borrowers use the service due to dire financial need and an unavailability of other credit sources rather than as a convenient alternative to traditional banking.

Further evidence of this can be found by looking at the way these firms advertise their position within society. At a Money Mart in Ottawa, Ontario, visited in November 2009, a sign on the customer service window read, "This Money Mart location is proud to support the Ottawa Food Bank this festive season. You can help the less fortunate in your community by donating the change from your transaction." By suggesting that the clientele of the Money Mart donate their change to the Ottawa Food Bank, this advertisement presumes that the customer is in a position of relative affluence, and thus is capable of donating to the 'less fortunate'. This type of representation consolidates the portrayal of the service as a middle-class convenience, rather than an act of desperation.

One can compare this representation to that present when pawnbrokers previously attracted their clients. As discussed above, brokers typically located their stores centrally within the poor neighbourhoods where they did business. As such, widespread advertising campaigns were not necessary for them to attract clients. Much like the local pub or church, they tended to be well known by those who used their services, and as such, firmly entrenched in their landscape. The simple symbol of the three golden balls displayed on a storefront was often all that was needed to let workers know that inside they would be able to find some relief from their economic hardship. As can be seen in the image of a strip of brokers in Omaha, Nebraska in 1938, brokers also tended to be concentrated geographically, aiding the process by which they came to be associated geographically with poor neighbourhoods. 

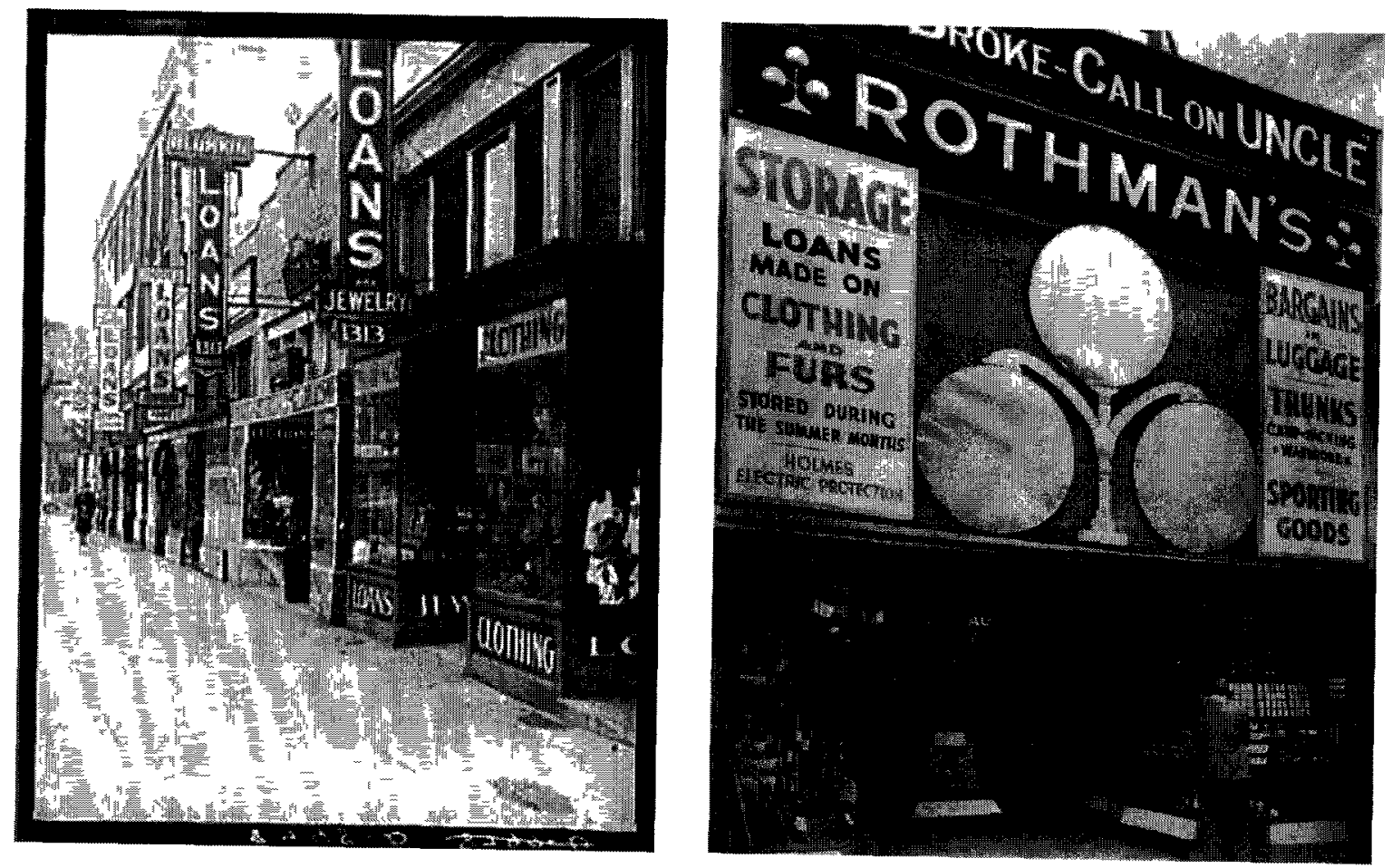

Figure 3 (Left): Loan Companies. Omaha, Nebraska (1938). Source: Corbis Images, photograph by John Vachon.

Figure 4 (Right): Rothman's Pawnshop. Manhattan, New York (1938). Source: Museum of the City of New York, photograph by Berenice Abbott.

This geographical concentration of pawn shops can highlight some of the assumptions that were made about borrowers during this period. By virtue of the fact that pawnbrokers were associated geographically with seedy, less refined areas, the borrowers themselves were explicitly assumed to be economically marginalized. Further, it was often the case that in the signage of the shop, reference may be made to its position within society. In the image above, one can see that Rothman's, a pawnbroker in 1938 New York, explicitly advertised his services directly toward those who were "broke." By highlighting the desperation of the borrower, the broker in this case explicitly associates his practice with the poor. When one contrasts this borrower representation to that which emerges from the payday lending experience, a stark contrast emerges; as one payday loan advertisement states, “Don't let money - or a lack of it - stop you from living life 
your way" (Cash Money, 2010).

\section{Constitution through the Event of Borrowing}

Finally, and potentially most importantly, the process by which the borrower actually gets the loan under each of these regimes can help illuminate the peculiarity of the current payday lending regime. The physical setup of the payday lender is fairly consistent between outlets. Typically, the front of the building is very open and, much like a retail shop, the interior is clean and attractive. As one study describes, the shops are often "well-maintained, and brightly lit with walls of big windows," making the atmosphere "professional, safe and welcoming" (Buckland et al., 2007, p. 51). The worker is usually separated from the customer by a glass service window, under which cash and the necessary documents are passed. Overall these spaces serve to present the payday lending experience as just another modern and legitimate element within the larger world of consumer finance. Bright, fluorescent, open and welcoming, they distance the payday loan from its seedy and dubious antecedents, establishing short term, highinterest credit as something that ought not be feared by the public and regulators, but rather embraced for the legitimate options it provides its consumers. 


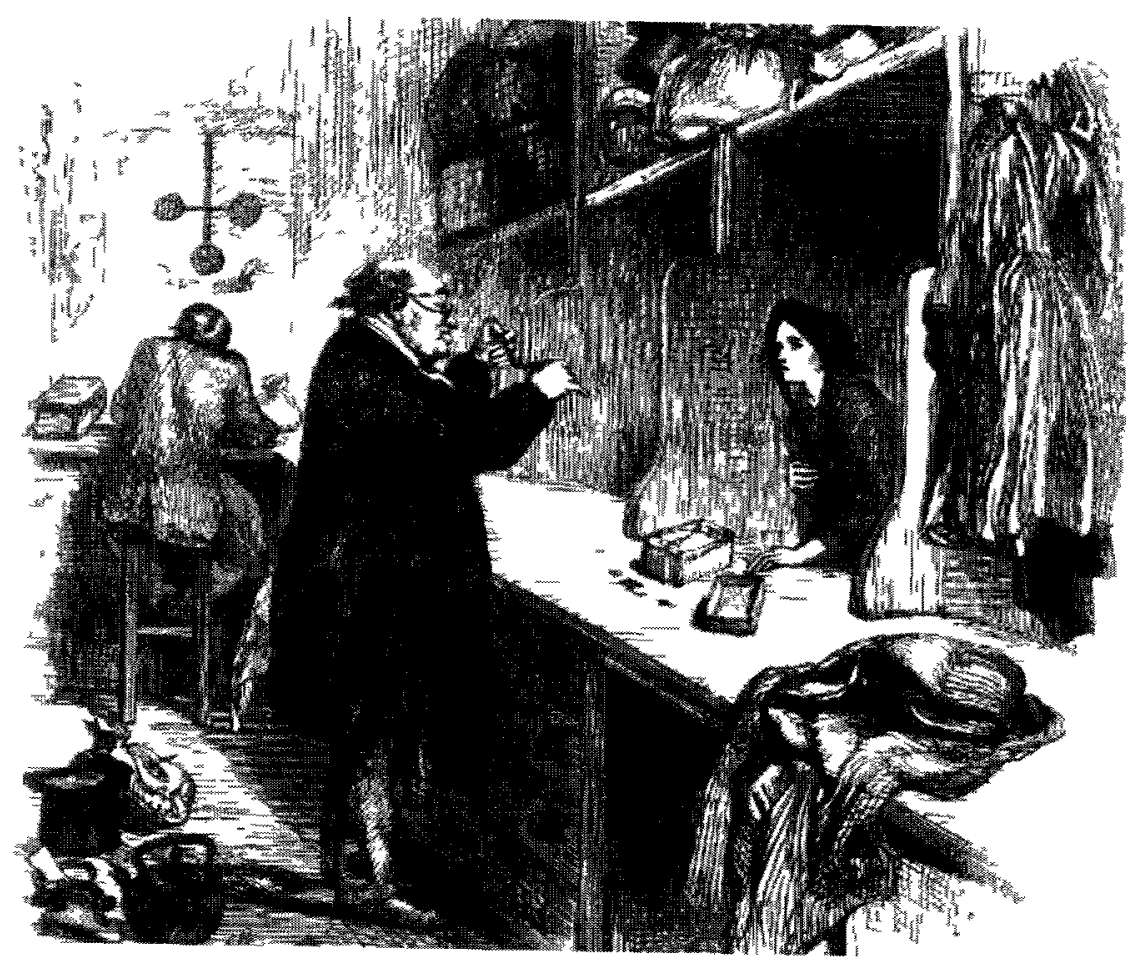

Figure 5: Inside the Pawnshop. (1862). Source: Database of Mid-Victorian woodengraved Illustration, illustration by John Gilbert.

During the pawnbroking transaction, conversely, the borrower entered a markedly different environment. As can be seen in the illustration above, the shop of the broker was designed in a particular way to cater to the needs of its clientele. Rather than having a wide open, well-lit space in which customers could interact with each other, the pawnbroker's shop was often divided into several private booths within which one could discretely converse with the broker. Charles Dickens described this venue in the following way:

The side door opens into a small passage from which some half dozen doors (which may be secured on the inside by bolts) open into a corresponding number of little dens, or closets, which face the counter. Here the more timid or respectable portion of the crowd shroud themselves from the notice of the remainder, and patiently wait until the gentleman behind the counter, with the curly black hair...shall feel disposed to favour them with his notice. (Dickens, 1835, p. 104)

Thus, we can see that the actual engagement between the borrower and the lender 
was largely mediated by the position of pawnbroking within society. Those who had to resort to using the pawnbroker's services sought privacy and anonymity when doing so, in order to avoid the scrutiny of others. Today, the spaces of fringe finance carry with them quite a different connotation; they have entered the public realm, been relatively destigmatized and reconfigured to become a welcome element within a modern, consumeroriented economy.

\section{Constitution through Collections}

While a comparison of the event of lending itself shows the very public side of payday lending versus the shady position that pawnbroking has historically held, when we shift our gaze to the chain of events that occurs when someone doesn't pay back the money that's been forwarded to them we see that a slightly different picture emerges. Payday lending is presented in a friendly and welcoming, consumerist light on the front end of the transaction and this is carried forward provided that the borrower holds up their end of the contractual agreement and pays back the loan on time. However, when the borrower misses that payment, and thus becomes a defaulter, the friendly, welcoming presentation of the loan quickly disappears and the more aggressive collection begins. While the liberal, choice-oriented aspect of this realm is important to highlight, it is equally important to explore the ways in which illiberal forms of control and harassment present in collections are integral to the functioning of this sector and, perhaps, the world of modern finance more generally. ${ }^{5}$

\footnotetext{
${ }^{5}$ This analysis pertains to collections done on part of both payday lenders and other mainstream creditors due to the fact that the data discussed relates primarily to registered collection agencies. It should be noted however, that there is evidence that because the inhouse collections of payday lenders are not done by registered collectors but rather (unregulated) company employees, there may be higher incidence of harassing and
} 
Pawnbroking, as noted above, was historically understood as a service directed at the poor and regulated as such. When a borrower wanted cash, they were expected to bring their goods into the pawnshop and put them up as collateral before a loan would be granted. From the beginning of the transaction, it was assumed that there was a high probability that the borrower would not repay, and thus the repossession process began when the borrower brought their goods to the shop. In the agreement, it was clear that in the event that the client didn't pay back the loan, their goods, which were usually of far greater value than the loan, would be immediately become the property of the broker. The transaction operated under these dubious and coercive pretences, justified on the grounds that because pawning was a service for the poor, one needed to be sure that in the likely event of default, the broker is still profitable.

Payday loans, on the other hand, are governed under two immensely different logics at the beginning and the end of the transaction. As noted above, they are initially presented in a consumerist light; they are advertised on the basis of convenience and as such the application process tends to be fairly rapid. No credit check is done. A standard set of questions is asked wherein the borrower needs to provide the name and contact information of their employer and a few personal references. They then need to write a postdated cheque to the lender for the loan amount plus interest and fees dated for the maturity date of the loan. From this, we can see that more agency is given to the lender in coercive collections techniques. It has been reported the employees at CashStore, for instance, get bonuses based on the amount they are able to collect (Complaints Board, 2010) and furthermore anecdotal evidence suggests that payday lenders are among the most ruthless collectors in terms of verbal harassment (Ottawa-based Credit Counselor, personal communication, Oct. 20,2010). With regard to registered collectors, there is evidence that some who deal primarily with payday lending clients engage in practices such as unlawfully debiting customers bank accounts (See, for example, Rip-off Report, 2011). 
the payday loan operation. Despite not having checked the individual's credibility, the lender assumes the ability of the borrower to repay the loan. There is no guarantee that the check in question is cashable, nor that the borrower has any history of repayment. Instead, in this application process, they are assumed to be a responsible and rational consumer subject who would not enter into an agreement such as this without knowing that they'll be capable of repaying the loan.

However, in the event that a borrower is unable to put together the funds for that post-dated cheque to pass, this trusting treatment is quickly replaced by harsh and invasive collection techniques which stand more in line with those of payday lending's antecedents than one might assume. The Canadian government noticed the issue of payday lenders using "threats" and other "inappropriate collection practices" as early as 2002 (Alternative Consumer Credit Market Working Group, 2002). Initially, when a customer defaults on a loan, collection is attempted in house by the frontline customer service staff. If this is unsuccessful, the debt is then handed to a different level, depending on the type of payday lending operation; firms such as Money Mart have centralized corporate collections offices, whereas smaller firms may just at that point hand it straight to a licensed collection bureau. In the event that the centralized collections offices of large firms are unsuccessful, the debt is most often sold off to a separate collections firm. While there is indeed legislation against certain forms of harassment on part of registered collectors, and stipulations on how often and whom collectors are allowed to call, there is substantial evidence that harassment still occurs frequently and interestingly, the forms it takes are quite in line with those that loan sharks used in previous eras.

While there has historically been very little in the way of academic literature on the 
nuances of the loan sharking industry, in 1941, the journal Law and Contemporary Social Problems dedicated an entire issue to the subject. In this article was one paper which focused solely on the collection tactics of these illegal lenders. Interestingly, while the author noted that there did indeed exist he publicly reported "brutal cases" involving thugs and violence, the "run-of-the-mill" collection methods employed by these lenders were typically centered around a different form of brutality - that which exploits the economic precariousness of the borrowers (Birkhead, 1941, p. 78). Comparing these tactics to those of contemporary collections firms and payday lenders reveals many similarities.

Just the threat of suing, with no intention of taking the case to court, will frighten many borrowers...Faked printed matter simulating legal process is not unusual in loan shark collecting. A folded paper can be dated and numbered to resemble a court summons, and bear a headline in red ink, 'Garnishee Demand and Supplementary Notice.' (Birkhead, 1941, p. 82)

It is very common for creditors, collection agencies, or collection lawyers to threaten to sue you if you do not pay your debt within a few days...in Canada it is perfectly legal for them to threaten you with a lawsuit even when they don't intend to. (Silverthorn, 2010, p. 22)

The threat of legal action on part of collectors has been and remains today one of the primary tools that these lenders use in motivating borrowers to pay their debts promptly. Despite the fact that in the vast majority of modern cases, it is simply uneconomical for collection agencies to initiate a court case against a borrower, often the thought of having to legally defend oneself over unpaid debts is enough to compel borrowers to pay. In these cases, one tactic that has been used heavily in recent years by collection agencies is to commission lawyers to send a 'draft statement of claim' to borrowers. This standardized legal document gives the impression that a lawsuit is imminent. While it is illegal for collection agencies to engage in this type of misleading behavior in many 
provinces, their lawyers have been known to use this tactic quite effectively. ${ }^{6}$ In 2008 , Ontario's Registrar of Collection Agencies sent a letter to collectors stating that this behaviour is "deceitful and misleading;" the registrar went on to "ask" that these firms cease in the practice (Appendix I). Despite this action, there has to date been very little enforcement related to this issue, prompting the Canadian Broadcasting Corporation (CBC) to feature it on their program Marketplace on March 4, 2011 (Smart, 2011).

Almost all illegal lenders "chase" delinquent borrowers relentlessly. They telephone a man at any hour at his work or at home. They call at his house. They may interview his neighbors. They may telephone a neighbor and ask that the borrower be called to that phone on the pretext that the borrower's line is out of order. They often send collect telegrams and special delivery letters late at night to awaken the borrower with a demand for payment. (Birkhead, 1941, p. 84)

One of the most effective ways for a collector to persuade someone to pay a debt is to humiliate him during a collection call. Most of the tactics a collector may employ to humiliate you are illegal. Some might call you a deadbeat or a loser. They might threaten to speak to your boss or the human resources department where you work. (Silverthorn, 2010, p. 21)

People come in here and say look my employer is threatening to fire me if I don't deal with this issue right now....They call anybody and everybody. They call friends, aunts, cousins, neighbours. Anybody they can to track you down. (Ottawa-based Credit Counselor, personal communication, Oct. 20, 2010)

Like the loan sharks of the past, collectors today rely heavily on sustained attempts to directly communicate with the borrower, using whatever means available to convince them to pay their debts. "They cast their nets wide and whatever the person reacts to....that's what they get harassed and pummeled on," one credit counselor remarks (personal communication, Oct. 20, 2010); “I've heard stories of people telling collectors

\footnotetext{
${ }^{6}$ One can find ample evidence of this trend on debt-related online forums such as www.canadian-money-avisor.ca where individuals seek advice on collections related matters.
} 
that they're terminally ill... and hearing 'well, you're better off dead than alive...you're a complete nuisance to society, people like you shouldn't exist"'. While legislation exists limiting the number of times agencies can legally call in a week and outlining the rules regarding harassment and 'unreasonable' pressure ${ }^{7}$, enforcement of these regulations remain weak. It is often more effective for the marginalized populations who are being harassed by agencies to employ tactics that help them avoid the harassment (e.g. changing their phone number, assigning an agent to communicate with their collectors, etc.) than it is to formally lodge a complaint against the firm (Ottawa-based Credit Counselor, personal communication, Oct. 20, 2010). As such, the coercive and often illegal tactics of collectors continue; in the words of one former collections lawyer, agencies employ many individuals "who break the law on a regular basis" (Silverthorn, 2010, p. 18).

When collectors are unable to directly contact the borrower, getting in touch with the people surrounding the individual - friends, family, employers - may often offer equally effective results. Birkhead (1941) documents how loan sharks in the interwar period would sent borrowers a copy of a letter drafted to their employer notifying him about the individual's failure to pay their debts (p. 83). It is recommended today that borrowers refrain from disclosing their employers' information to collectors at all costs for just this reason; there are numerous well-documented examples of collectors tarnishing the reputation of borrowers by collecting their employers and notifying them of the individuals' bad debts (Ottawa-based Credit Counselor, Personal Communication,

${ }^{7}$ In Ontario, for instance, collection agencies cannot legally call more than three times in a seven day period on behalf of the same creditor, nor can they legally use "threatening, profane, intimidating or coercive language" (Collection Agencies Act, 1990). 
Oct. 20, 2010). However, as noted above, as part of the payday loan agreements, customers are most often required to provide their employer's, family and friend's contact information prior to receiving the loan, which makes these collections techniques more readily available to these firms.

From these examples we can see that the choice-oriented, consumerist light that the payday loan event is initially presented in quickly disappears once the borrower fails to pay back the loan. While previously, the entirety of the pawnbroking transaction was organized under the assumption that the borrower was marginalized, today the payday loan is initially presented as a legitimate modern financial service, but once this consumer turns into a defaulter, the coercive and invasive collections practices that were often utilized under the previous loan sharking regime come to the fore. This stark dividing line between the initial consumer and the fraudulent defaulter reflects both the precariousness of the payday loan event in the contemporary context and the odd relationship that this service and finance more generally have with the antecedents of the fringe finance sector. While it is tempting to characterize modern financial consumers in a neoliberal, choicefocused light, looking at the way in which these individuals are treated in the event that they don't live up to their creditors expectations of responsibility shows us that this obscures an important aspect of the financial world.

\section{Conclusion}

By comparing the pawnbroking event with that of the payday loan, it becomes clear that the current act of borrowing from a fringe-lender is a vastly different experience than it was in previous eras. While before, the pawnbroker was presented as a rather dubious, seedy locale in which one privately sought money when all other options were exhausted, 
today, the payday loan presents itself as a safe, legitimate market transaction which one should not find shameful or distressing. The payday lender assumes the comfortability of the clientele with the transaction, whereas the pawnbroker took deliberate steps to ensure the client's anonymity. While today, the technologies governing the lenders actions are primarily economic and calculable, the pawnbroker was previously engaged in his community and thus regulated to some extent by the social values therein. In a way, the transaction has been brought into the public realm, and is no longer limited to the same extent by negative perception. As such, access to fringe lenders has been broadened and there currently exists more space in which nuanced regulation of the sector can occur. At the same time though, this arrival of the payday loan as a public and legitimate service serves to normalize the use of the fringe finance sector by sometimes marginalized populations. With this normalization/publicization, the economic position of the borrower within the transaction in many ways disappears; fringe lending is no longer presented as a service that is depended on by the poor, but rather just another option in the choice-laden world of finance. This becomes problematic when one considers both the high interest rates that borrowers are expected to pay for these loans as well as the coercive collection and harassment techniques lenders employ in the event that the borrower is unable to repay.

But what are we to make of these changes? Where did the emergence of payday lending come from, and what does it mean? Surely, the dominance of the current payday lending regime could not have come about where it not for the myriad of both ideational and economic transformations which preceded it. For instance, real wages have fallen dramatically in recent decades (Pollin, 2005); this has created a vast number of low- 
income workers who, while being engaged with mainstream finance vis-à-vis their bank accounts, lack other credit options when they are struggling. Without this demand from low-income wage-earners who lack alternative short term credit options, the industry simply could not exist. Similarly, with employers increasingly opting to pay their employees using direct deposit since the 1970s, the ability of workers to access informal networks of short-term credit has been limited. Whereas previously, it would have been more likely that workers could ask for salary advances of a few days from their employers, under the increasingly formalized direct deposit regime, this informal source of short-term credit is becoming increasingly rare.

By showing how these different fringe finance events differ in a number of ways, this chapter has sought to highlight the ways in which our current understanding of usury and its relationship to marginalized, low-income financial subjects is a contingent one, which is both shaped by and serves to shape both our views of the poor and the practices of the fringe finance sector. If how we understand a concept - such as usury - within our practices and discourse shapes the conditions of possibility within which we engage with it - socially, economically, politically - then this type of analysis is valuable. When the poor are lost within the 'legitimate' and public consumer realm of the payday loan, our understanding of both what it means to be poor and how we deal with economic exploitation takes on a very peculiar character. By looking at the current configuration against a pawnbroking regime, this becomes quite clear. 


\section{Chapter 3: Governing Usury}

Thus far, this analysis has engaged with both the specific types of problematization that has surrounded the official legislative response to usury over the past century and the position of various usurious practices of over time, highlighting the novelty and conditions of emergence of the payday loan event. It has attempted to show both the contingency of the current position of usury within our society and the subtle ways in which practice, knowledge and economy have intersected to constitute the political and moral foundation on which this problem sits. The final chapter of this analysis is thus left with the broader question of governance. What specific government approaches has this constellation of discourse rendered advantageous and what approaches has it rendered inappropriate? What are the specific tools that the state is using to govern the fringe financial sector today and in what ways are these consistent with and/or departures from previous approaches? How do they reinforce and/or render obsolete the truths highlighted in previous chapters regarding the issues surrounding poverty?

As was mentioned in previous chapters, a primary means through which consumer credit is currently problematized within government discourse is 'financial literacy'. This chapter will highlight the rise of financial literacy as a tool of governance within the Canadian context. It will show the complicated political process whereby this approach displaced the hegemony of the ethic of thrift, which can be seen as a primary form of economic responsibilization in the era preceding the Second World War. Finally, it will show how current critical responses to the problem of high-interest lending, which are largely housed today within the discourses of 'community economic development' 
and 'financial exclusion' are in many ways drawing on and reviving aspects of the thrift ethic in their reconstitution of the usury problem. While this should not be read as a direct translation of pre-war thrift, due to the fact that it redeploys only aspects of the narrative onto the vastly altered political terrain of today, it one can see how some aspects of this ethic, namely the conscious mobilizing of funds for socially oriented investment is in keeping with many tenets of the previous approach.

\section{The Problem of Financial Literacy}

Our economy is built on millions of everyday financial decisions by Canadians. Recent events have shown us that there are major risks and that financial literacy is an important life skill. Whether it is a question of saving for retirement, financing a new home or balancing the family chequebook, improving the financial literacy of Canadians will add to the stability of our financial system and make our economy stronger. (The Honourable Jim Flaherty, Minister of Finance, in his speech announcing the launch of the Task Force on Financial Literacy, June 26, 2009)

In the wake of the 2007-2008 economic crisis, as personal finance rose to the fore as a prominent political issue, the Government of Canada solidified its commitment to empowering Canadian consumers to make wise financial choices. The Minister of Finance, Jim Flaherty, commissioned the Task Force on Financial Literacy, a committee made up of thirteen of the country's most notable bankers, financial advisors, consumer advocates and debt counseling experts. Their mandate was to hold public consultation sessions across the entire country and learn from Canadians both the state of financial literacy in the country today and specific ways in which the government can better arm consumers with the knowledge they need to navigate the world of finance. During their consultation period in early 2010 , the Task Force received over 300 written submissions and held public consultation sessions in fourteen communities (Task Force on Financial Literacy, 2010a). The Task Force's final report was released in December of 2010. 
This Task Force is just one element of a sweeping government initiative to teach an ethic of prudent financial self-governance to Canadians. In 2006 the Standing Senate Committee on Banking, Trade and Commerce (SSCBTC) released a report entitled Consumer Protection and the Financial Services Sector: The Unfinished Agenda. This report called on the government to premise its approach to consumer protection on the dual principles of disclosure and competition, which "together contribute to attaining the ultimate goal of providing affordable and innovative financial products and services to consumers" (SSCBTC, 2006, p. 53).

We believe that enhanced levels of information and education will lead to both better decision-making by consumers, since they will have better information with which to make financial services decisions, and greater competition among financial services providers, which will compete with one another for the better-informed consumers. (SCBTC, 2006, p. 57)

In keeping with this notion of improving Canadian's decision-making ability, the Committee recommended that the government increase funding to federal departments, primarily the Financial Consumer Agency of Canada (FCAC), to aid in their mandate of consumer education (SCBTC, 2006, p. i). Since this time, financial literacy components have been added to the school curriculum Ontario (Ontario Ministry of Education, 2011) and the Government of British Columbia has been working closely with the FCAC to develop literacy tools for high school students (FCAC, 2008).

Evidently, there is currently a targeted push toward responsiblizing Canadians and promoting a regime of self-governance as a method of regulating the interface between individual consumers and the complicated world of finance. Before one can fully engage with the meaning of this project though and the subtle ways in which it became possible to understand this complicated consumer-finance relationship in this way, one must first 
be able to contextualize these programs within the broader history of economic responsibilization.

\section{Responsibilization through the Generations - Thrift, Consumption and Financial}

\section{Literacy}

To fully understand both the position and novelty of the current problem of financial literacy, it is imperative to contextualize it within the broader history of government policies aimed specifically at shaping how each individual citizen engages with the economy. Currently, there is much in the way of very interesting literature that deals with the recent trends in responsibilization and its relationship to finance (see, for instance, Williams, 2007, Aitken, 2010). These studies tend to place the trend in conversation with the rise of the 'enterprising self,' a neoliberal subject, cultivated through programs and policies reliant on a rational and sovereign economic actors (Miller \& Rose, 2008). While my argument doesn't doubt that this trend is present, I contend that to better understand its novelty, and more importantly, to gain insight into the ways in which the political battle surrounding this responsiblization is currently unfolding, we must first look to history. Only then will we be able to recognize the historical contingency of this responsibilization and understand how over time elements from past regimes have maintained an existence beneath the surface only to reemerge as politically poignant in the current context.

Government's have long been in the business of 'shaping the economic imagination' of their citizens. If we take seriously the thrust of the wide literature on how individual subjectivity is shaped through both economic discourse and action (See, for instance, Gibson-Graham, 2006, p. 23-53) we can begin to make sense of the effects of 
government programs and moral imperatives which aim to shape how we understand 'economy'.

The discourse of thrift has a history that long predates the scope of this study. Weber linked its tenets - an emphasis on hard work and the necessity of savings for future investment - to what he termed the 'protestant ethic,' a moral outlook that can be linked back to Calvinism which he saw as laying the foundation for the rise of capitalism in Western Europe (Weber \& Parsons, 2003). In this reading, morality became explicitly linked to one's ability to work hard, practice self-restraint and to effectively plan for the future. This ethic rose to dominance during the Victorian period; as one analyst notes, "thrift became a yardstick upon which personal consumption was observed and morally evaluated...temptation and idleness required exorcism as they thwarted the productive drive....correct consumption, thrift, temperance, and self-restraint marked moral respectability and social standing (Botterill, 2010, p. 27).

If we are to map the specific methods by which this ethic was mobilized and deployed during this period, it is useful to begin by examining the writings of social reformers; both fictional and non-fictional works on the importance of economic prudence and hard work pervaded this era. Thrift figured prominently into the works of Benjamin Franklin, for instance (Blankenhorn et al., 2009) and was glorified in novels like Defoe's Robinson Crusoe (1719). Others made their entire careers out of publicly extolling the virtues associated with this ethic. One such writer was Samuel Smiles, a Scottish author who was widely cited as a guru of self-reliance and an expert in the power of thrift not only to help the individual, but more broadly to bring positive impacts to society. Smiles' wrote books on a wide range of topics relating to man's relationship with 
economy, his most famous being Self-Help (1860), which by 1901 had been to press fifty times and translated into a number of languages. In his third book, Thrift, which was released in 1875, he extols the virtues of each individual "spend[ing] less than [they] earn...and never, on any account...run[ning] into debt;" (Smiles, 1875, p. 104) these foundations of thrift, he demands, will not only bring happiness, but also "impart strength to the character...produce a well regulated mind [and] foster temperance" (Smiles, 1875, p. 33). In Smiles' work, thrift stood not only as a tool for skillful and economic living, but was also very implicated in discourses of the moral life. He emphasized the ideal of a provident life, build on prudent forethought and self-restraint; thrift "gave virtue the mastery over self indulgence" and in doing so stood as the foundation on which one could build a dignified and moral existence (Smiles, 1875, p. 33)

Looking for examples of how these ideas have been mobilized and redeployed in the Canadian context, one can find striking evidence from the beginning of the $20^{\text {th }}$ Century. For instance, in 1903 the government passed the Penny Bank Act to formalize and regulate the savings plans that were being developed in Toronto Schools. Originally developed in 1875 in the city by Rev. D.J. McDonnell, these systems gave youth an opportunity to formally save their money; they were heralded for teaching children to be "thrifty and independent" and "correcting the prevailing tendency...to spend money as it was acquired” ("Penny bank system," 1908).

During war times, these efforts on part of government to encourage savings became even more pronounced. As the Canadian Government's resources were being drained by its commitments on the European Front, the notion of thrift was extensively drawn upon in massive public awareness campaigns which sought to responsibilize 
ordinary citizens. In the Ontario School Curriculum, for instance, during World War I students were taught the simple lessons of making their consumer products last longer in an effort to free up labour for the weapons industry. "If a man is occupied in making boots for you, he cannot at the same time be occupied in making boots for a soldier," a teaching pamphlet suggests; "abate your needs or comforts or luxuries...make your boots last longer than before" (Ontario Dept. of Education, 1919).

In addition to this ethic of anti-consumption, schools also played a key role in emphasizing for youth the importance of savings and linking this thrift ethic to nationalist ideals. One method by which this was encouraged was through the sale of Thrift Stamps. For twenty-five cents, students could buy Thrift Stamps at any post office. Once they had collected sixteen stamps on a Thrift Card they could exchange it for a War Savings Stamp, worth the total $\$ 4.00$ they had then saved, which would increase in value to $\$ 5.00$ on January 1, 1924 (Ontario Dept. of Education, 1919). Here we see an example of how to make thrift accessible for portions of the population, certain technologies needed to be invented and implemented; the government put in place a program that was specifically designed to make thrift an accessible and rewarding enterprise for children who previously had limited avenues for formal savings. By tailoring patriotic investment products to youth in this way, the Government was very successful in embedding the notion of using saving and self-restraint for the purposes of social good in entire generations of young Canadians. 


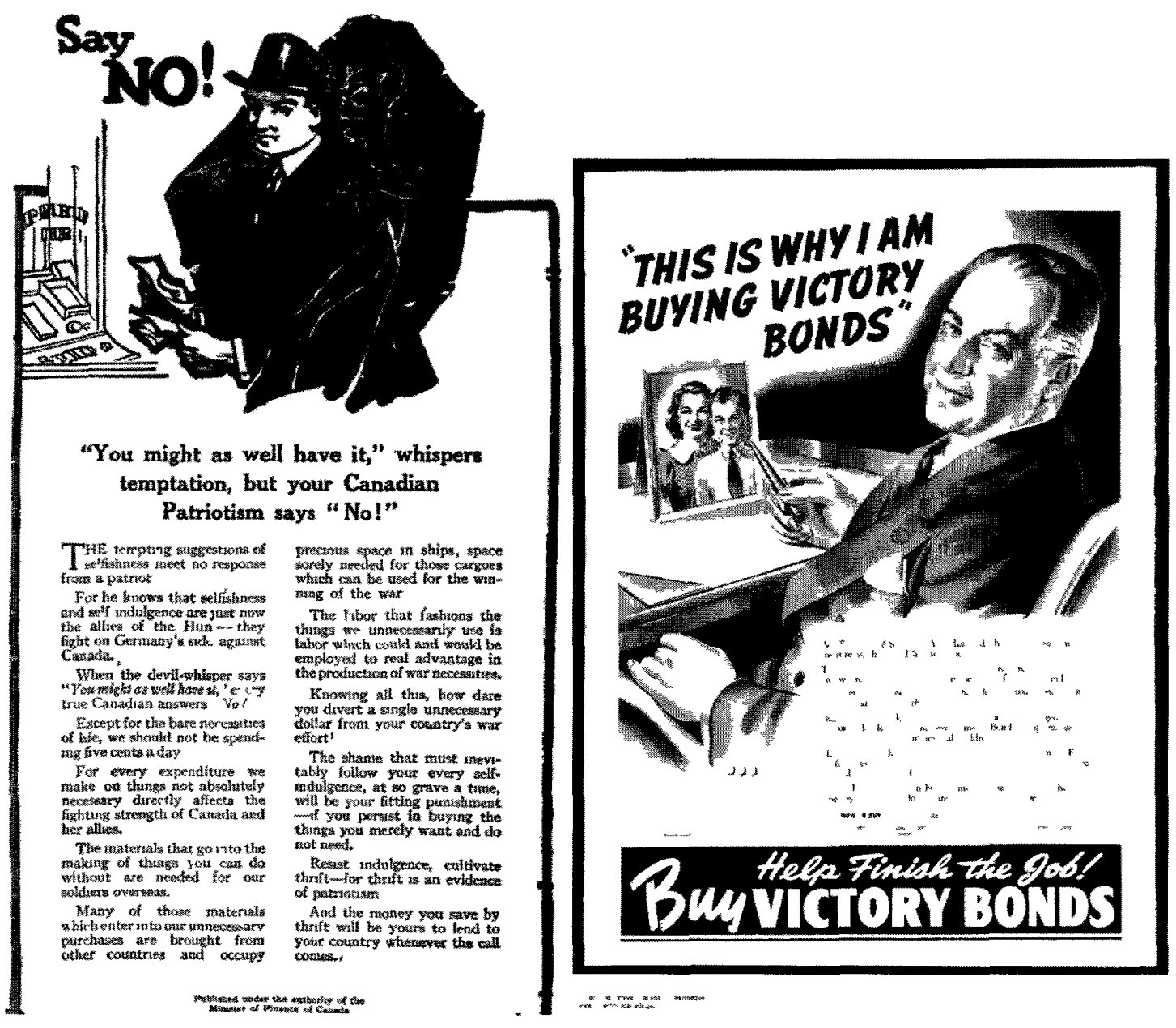

Figure 6 (Left): Say NO. (1918). Ministry of Finance of Canada. Source: Toronto World, Sept 30, 1918.

Figure 7 (Right): This ts Why I am Buying Victory Bonds (1939-1945). National Committee Victory Loans. Source: Library and Archives Canada.

It wasn't only children to whom this equation of savings and the social good was

aimed. In the above advertisements we can see that any excess consumption by any segment of the population was deployed as an actıvity worthy of contempt. "Resist indulgence, cultivate thrift - for thrift is an evidence of patriotısm," one government advertisement suggests (Figure 5). Temptation, here, is equated with a black, shadowy devil trying to lure the diligent citizen, the "true Canadian" off of the good path of prudence. In the second advertisement we see explicitly the attempt to equate thoughtful, 
socially-minded investment with moral action. The character reminisces, "where a man's treasure be, there will his heart be also," then professes "I may not be in the front line myself, but my dollars are certainly going to be" (Figure 6). Here we see an incredible example of the way in which savings and conscious investment were tied to notions of good citizenship, patriotism and the social good. By directly linking how one handles their money to the value of their societal contribution, the mobilization of war thrift in many ways laid the foundation for the current culture of ethical investment.

It should also be noted that it was not only during war times that the ethic of thrift was deployed by the government. In the interwar years as well, both the Canadian government and those of the provinces sought to promote this prudent relationship between the consumer and the economy at large. One such program in Prince Edward Island sought to "encourage buying on a cash basis and...to do away with the installment plan system of purchasing" in hopes of "assisting ordinary people in solving their own financial problems" ("To encourage thrift," 1936). By encouraging individuals to pay for goods up front in this way, rather than relying on store credit, this program took a stance against the growing consumer credit trends and pushed thrifty self-reliance. Similarly, in Saskatchewan, the Chairman of the War Savings Committee, Mr. Lamont stated in 1918 that because "teaching thrift in schools has been found beneficial from so many points of view besides that of raising money... from now on it will be a subject as much in demand and as faithfully taught as reading, 'riting or "rithmetic" ("Teaching thrift in schools," 1919). From this we can glean that this ethic was a pervasive aspect of the discourses surrounding how one ought relate to the 'economy' during this entire period. 
In using this discussion to contextualize current debates, it is interesting to note the extent to which the ideal of the thrifty and prudent consumer is purported to have universal purchase. There was some question in public discourse about the ability of and/or responsibility of all members of society to engage in this type of thrift campaign. As was noted in Chapter One, a primary division of society during this period was understood to be class, however the level of autonomy and responsibility of the poor was a contested topic. On the one hand, proponents such as Smiles advocated thrift for all, even those struggling with meager earnings, citing that many "industrious and sober men" do in fact "deny themselves and put their spare earnings into...receptacles provided for poor men's savings" (Smiles, 1875, p. 26). Others, though, publicly took a less liberal perspective, suggesting that the class divisions that existed within society warranted accommodation for those who may not, due to material or structural factors, be capable of living up to the patriotic ideal cited above. One article in the Toronto World during the First World War suggest that "it goes without saying the thrift injunctions are not intended for the thousands of salary earners, people on small fixed income, and other who have had no increase and in many cases a reduction in their stipends since the war broke out" ("Thrift and the thriving," 1918). Here we can see that the relationship between the ethic of thrift and those who "are unable to help themselves" ("Thrift and the thriving," 1918) was a complicated one which reflected the changing knowledge of the poor that characterized the times.

Outside of thrift's relationship with the poor deprived classes being an issue of contestation, it is also interesting to note the process wherein the entire ethic of prudence itself came under fire. While the campaigns outlined above reflect the government's 
consistent advocacy of thrift during the period up to and including World War II, the legitimacy of this type of relationship between the individual and the economy was called into question long before the late 1940 s. As early as the 1930 s, the idea of thrift itself was becoming contested in public discourse. There was a new understanding of 'the economy' emerging wherein the individual consumer bore a responsibility to strengthen the economy (and in turn the nation) through their activities in the marketplace. Within this new Keynesian body of knowledge, the social responsibility present in the thrift ethic as non-consumption and prudence was redeployed as the very act of consumption itself. Thrift was becoming increasingly contested as anti-social behaviour, as that which would foster stagnation in the economy and create unemployment on a massive scale. In the 1930s, as unemployment was a rampant and intense political debates over its causes and effects pervaded, thrift became for many an object of scrutiny. As the then Editor of the Ottawa Citizen wrote in a column in 1936, prescribing thrift in a time of unemployment is "the very acme of absurdity, the limit of unreason;" "the only rational cure," he suggests in his piece is "more spending, a greater volume of consumption" ("Under-consumption," 1936). This contestation continued through to the Second World War; while some were still ardently engaging in the thrift campaigns set out by the government, others publicly denounced the approach as "a dangerous doctrine for...times of peace" because, as one journalist put I, "thrift and prosperity simply don't mix" given that "our whole economic system depends on consumption" ("Is thrift dangerous," 1943).

Despite this politicization by some of thrift as an anti-economic behaviour, the response to the discursive shifts surrounding the economy during this period was mixed. In 1950, for instance, years after the end of the Second World War, the National Council 
of Women in partnership with the newly founded Canadian Association of Consumers launched a campaign entitled Why Be Thrifty? which sought to "bring back into the lives of Canadian families the lost knowledge of thrift" (National Council of Women, 1950, p. 1). What is most interesting about this post-war deployment of the ethic though is the terms on which thrift is to be understood. Previously, in the writing of authors such as Smiles, thrift was simply a proper way to live in and of itself; it carried a moral component with it, and was seen to be a sign of character, a method of thoughtful living, underpinned by foresight and prudence. When thrift was deployed during war times, as shown above, it carried an instrumental quality - savings equaled more money to invest with the government which in turn equaled a stronger war machine to fight abroad; in this deployment nationalist concerns and defense displaced the moral undertones of Victorian thrift. In the post-war deployment by the National Council of Women, though, the instrumental idea of thrift carried forward, but to a much different end: the 'war' against inflation. Here 'the economy' is presented as a rational, bound object of intervention and thrift is seen as the tool by which the ordinary consumer can affect it in a way which effects all consumers in a positive way; it will not only "enable families to make their money go further in a period of inflation" but "also help to bring down prices" (National Council of Women, 1950, p. 1). This is attributed to the fact that "spending lavishly in our own country...keep[s] up demand for consumer goods and contribute[s] to the creation of scarcities which keep prices high" (National Council of Women, 1950, p. 7). Thus, by replacing the moral obligation previously associated with thrift to rational selfinterest based on a modern understanding of economic laws, this campaign attempts to redeploy a historically recognizable ethic onto a terrain which is increasingly consumer- 
oriented. Furthermore, there is a recognition in this campaign of the concerns of the antithrift critics; the authors cite the fact that because consumer habits are so diverse, the negative impacts of thrift on the health of the economy will be spread out.

People will not all practice thrift in the same field. Some people will save on clothing, some on using the car less, some in buying and preparing food. No two families will follow the same thrift habits. This is good because it will spread the effect of the thrift campaign throughout the whole country and no particular industry will suffer unfairly from its effects. (National Council of Women, 1950, p. 5)

Here we see that in promoting thrift during a period when commonsense understandings of the inner workings of the economy are in vast transition, the authors needed to couch their campaign within Keynesian pro-consumption discourse for it to have legitimacy. Attention was paid to the fact that the moral thrust of thrift was slowly being eroded by an ethic of nationalist consumption.

It is interesting to note as well, though, that in this time of transition the authors of this campaign also in the last page of the pamphlet tried to appeal to the widely understood mandate of national defense in their remarketing of thrift. They state that "[c]ommunists recognize inflation as a weapon of war" and that "democracy's strength lies in a sense of individual responsibility." "It is necessary to make ourselves strong as a nation," they contend, "not only through military measures but also by demonstrating that self-discipline can be effective" (National Council of Women, 1950, p. 7-8). Thus, we see that while the authors are on the one hand trying to deploy thrift on the new terrain of primarily economic rather than moral or social responsibility, in the end they link this economic responsibility to the long understood nationalist defense concerns which the government had previously associated with thrift as means of making the cause more recognizable. 
Despite the salience that the ethic of thrift still had to some during this period, changes were occurring in the way that the government sought to responsibilize citizens. Much has been made of this time in history by many authors from a number of different theoretical perspectives. Sociologists such as Bauman highlight the rise of a 'consumer society' which is said to have replaced a society in which production was the primary organizing factor (see Bauman, 2005). In the Marxian school, Marcuse points to the pitfalls of the rise of consumerism as a primary source of meaning in the lives of western subjects bound by what he termed instrumental reason. In this reading, it is suggested that the rising significance of consumerist 'false' needs, a product of the burgeoning advanced industrial society, were spawning a placated and sterile one-dimensional consumer society which lacked critical reason or revolutionary potential (Marcuse, 1991, p. 5-7). In an earlier analysis published in 1958, Arendt (1998) was equally critical of the modern "mass society" in which the private realms of politics and action have been eclipsed by an all-encompassing social totality that includes all members of society. In this reading, conformism and normalization have come to preclude meaningful political agency; this "rule by nobody," she writes, may come to represent one the "cruelest and most tyrannical" styles of rule humanity has ever seen (Arendt, 1998, p. 40).

These interpretations of this era are rather totalizing in their implications and in my view don't fully account for the nuanced processes by which the changes I am discussing occurred. While it is easy to periodize the post-war decades and suggest that 'consumerism' rapidly emerged, radically reconstituting the organizing principles on which social problems, critical action and capital accumulation rest, this type of interpretation doesn't do justice to the complexity with which these changes occur. 
Similarly, approaches which look at these changes and attribute them to the logic of capital accumulation, such as that of Marcuse, fail to account for the myriad of divergent paths that social change may take, all within the limits of possibility that are imposed by how we understand capital to operate. For instance, in this discussion, it is of paramount importance to note that the 'consumer' discourses that emerged and served to govern regulatory approaches during this period did not arise out of a vacuum. Both the way that individuals understood their relationship with the productive sphere and how 'the economy' was generally understood to operate were contingent products of complex political histories which very much include the discussion of thrift outlined above. As I have shown, government programs have sought to modify consumer behavior at least since the early $20^{\text {th }}$ Century in Canada. Furthermore, as Trentmann (2006) has shown in his extensive genealogical analyses, the consumer subject has been mobilized in a myriad of diverse and contested ways dating back to the late $19^{\text {th }}$ century in the European context. As such, it is extremely difficult to picture "a natural synergy between the consumer, individualism, and neoclassical economics" as is the case in many epochal analyses of the post-war era; the consumer is a contingent, non essential entity and its mobilization in the recent half-century under self-interested and liberal pretenses is just one moment in a long line of political subjectifications, some of which emphasized social responsibility and solidarity rather than autonomy (Trentmann, 2006, p. 42). This analysis is reinforced by Miller and Rose (1997) who emphasize the complicated and problematic cultural processes - the "unprecedented and meticulous cartography" - by which "the consumer' was created as an object to be known and studied in the realm of psychology during this period (p. 6). 
With this caveat in mind, it is interesting to note the shifts in the way the Canadian government sought to foster a new understanding of the role of the individual citizen visà-vis the economy in the post-War period. As Keynesian ideals of full employment gained more traction, and government programming began to increasingly understand consumption as a positive and productive phenomena, the ideals of thrift became far less prominent in social policy. Through the 1950 s and 1960 s, we witness a tremendous rise in personal financial products such as retail credit for home appliances. Consumer loan companies in 1963 had 359\% more credit outstanding than they did a decade prior (Special Joint Committee of the Senate and House of Commons on Consumer Credit and Cost of Living, 1967, p. 67). In light of these changes, the government's response reflected a new, more liberal appreciation of both the potential benefits of credit and the ability of individuals to manage their own relationship with creditors. In 1967, the Department of Corporate and Consumer Affairs was commissioned to work on issues surrounding the expansion of consumer credit as well as misleading advertising and fraudulent behavior (SSCBTC, 2006). The negative view of credit that was prevalent within the thrift discourse was displaced by the need for each consumer to be cautious and thoughtful in their use of credit. It is during this period that we witness the emergence of consumer education programmes which act as a foundation for today's deployment of financial literacy.

For instance, in 1970 the Department of Consumer Affairs distributed 75000 copies of a booklet entitled Consumer Credit to schools, consumer organizations, radio broadcasters and lending institutions. The book sought to educate citizens on the "pitfalls" sometimes associated with the "enticing world of easy credit," offering tips on 
how to use credit wisely ("Ottawa booklet tells of pitfalls," 1970). It advocated consumer tactics such as shopping around to find the best terms and paying as large a down payment as possible to avoid high interest charges. Here we see the seeds of the new problematic surrounding individual economic responsibility that eventually emerged. The forms of knowledge that one previously needed to be a thrifty citizen were being slowly replaced by new concerns about how to be a responsible borrower and investor. Savings become but one tool in a complicated new consumer-centered problem-space and, in turn, new forms of expertise were being born. Prudence and economy took on novel meanings as more emphasis was placed on a relatively self-regulated market. However, when one looks at the extent to which this new responsibility was expected of all subjects, it becomes clear that during this period, while the notion of the consumer carried much weight, all consumers were not seen as equal.

Much in the same way that thrift discourses of previous eras were not necessarily deployed to all segments of the population, the responsibilization programmes of the new field of credit counseling understood society as divided along the lines of class. For instance, in 1976, the Department of Consumer Affairs opened up nineteen regional consumer offices which specifically targeted 'low-income consumers'. The storefront locations in large urban centres across the country were intended to provide the credit advice that marginalized groups specifically needed to deal with the burgeoning financial sector. By targeting low-income groups in their programming in this way, Consumer Affairs made it clear that the problems associated with credit are different for different segments of the population. 
This sentiment is echoed quite vividly in the 1967 Report on Consumer Credit, penned by the Special Joint Committee of the Senate and the House of Commons on Consumer Credit and Cost of Living. On the one hand, this extensive document reflects the shift toward placing a greater level of expectation on the consumer to thoughtfully navigate the financial world. It in no way condemned the use of credit, but rather advocated more stringent truth in lending legislation as to create a better functioning marketplace. Specifically, the Committee recommended that "every person, firm or corporation...carrying on the business of extending consumer credit, shall be required by law to disclose...the total cost of that credit expressed both as a lump sum and in terms of simple annual interest" (p. 3). By giving consumers the information necessary to make rational credit decisions, it is suggested that competition will result in reasonable prices for credit and thus all consumers will be better off.

However, this liberal disclosure-oriented approach did not make up the thrust of the document. Rather, the primary recommendation by the Committee was that the government develop financial products specifically to meet the needs of those consumers on the margins of the financial world.

In order to prevent low-income families from becoming mired in debts from which they can never hope to extricate themselves, we recommend that the federal government make available, through the regular banking system, guaranteed consumer loans under specific conditions to all with annual family incomes of $\$ 4000$ or less. The loans would be repayable over an extended period, and would bear a low rate of interest. They would be made only for provident and productive purposes related to the preservation of home and family. The maximum size of such a loan would be $\$ 1,500$. (p. 4)

Here we see the explicit suggestion that not all members of society engage with the world of finance in the same way. There is an acknowledgement that there is a certain class of 
individuals who "often pay the highest interest rates and are in the greatest need of protection" (p. 21). To mitigate the "tremendous economic, social and psychological load" which faces this "vulnerable group" the Committee advocated interfering in the free market as a tool in the "fight against poverty" (p. 4). In their rationalization of this plan, the committee make explicit that the government has a long history of interfering in the market to "[fulfill] a socially desirable need;" the authors cite numerous examples of the government extending inexpensive credit to vulnerable groups such as the Farm Improvement Loans Act, The Veterans Business Act, and the Farm Credit Act. By emphasizing truth in lending legislation, yet at the same time problematizing the free market approach to credit in this way, the report is a great representation of the shifting body of knowledge around the relationship between credit and society during this period. While the decline of thrift and the rise of Keynesian ideals of consumption made credit more legitimate, and created some space in which a free market approach could flourish, the lingering understanding of a class-divided society combined with the Keynesian concern for social welfare made possible targeted interventions which sought to address the structural inequalities on which the problems associated with credit often unfold.

When we compare this report to its aforementioned analogue, released in 2006, we see that while the importance of 'consumer education' regarding credit maintained its importance and blossomed into a primary mandate in its own right, the notion that credit doesn't have the same effects on all parts of the population has fallen from the fore. Rather than targeting class divided groups in credit programming, the 2006 Report calls for an increase in the amount of funding toward financial literacy education. Similarly, the 2010 document released by the Task Force on Financial Literacy calls for financial 
literacy programming to be programmed into the school curriculums of all provinces (Task Force on Financial Literacy, 2010b, p. 34) and to be deemed an "essential skill" in the Government's Essential Skills Framework, a tool used to identify the tools and skills that Canadians need to succeed in life and lifelong learning (Task Force on Financial Literacy, 2010b, p. 32). To better understand what exactly this implies, and the assumptions that are made in this policy mandate, one must interrogate the actual government departments and programmes which it has spawned.

\section{The FCAC and the Politics of Financial Literacy}

The FCAC, the recipient of much of this new financial education funding, was founded in 2001 with the dual mandate of protecting and informing Canadian financial consumers. On the protection side, the organization ensures that federally regulated financial institutions comply with consumer protection measures. When it comes to informing consumers, though, their programming focuses on creating tools that will aid in promoting financial literacy among large groups of the population. Once they have created these products, they distribute them through a network of community-based organizations, schools, and NGOs which use them to deliver the on the ground financial literacy training.

In analyzing the logic under which the 'problem of financial literacy' is currently understood, one can begin by simply looking at who these programmes target and compare these populations to those of previous responsiblization regimes. In my discussions with the FCAC, it became clear that the primary groups which they target in the design and deployment of their literacy tools are high school students (through The City, an online workshop designed for use by teachers) and young adults, newcomers to 
Canada and low-income Canadians (through their other program, Financial Basics). ${ }^{8}$ The logic behind targeting these groups is firstly "to catch them before they get into problems" with debt, and secondly, for those who have already been exposed to some of the problems associated with debt, "giving them instruction on how to deal with that" (FCAC official, personal communication, Oct. 27, 2010). The Task Force on Financial Literacy, similarly, identified Aboriginal Canadians, young adults, low-income and lowwealth groups as currently struggling with many areas of financial literacy (Task Force on Financial Literacy, 2010b, p. 14, 45, 46, 49, 52). The Task Force's data, in this case, comes from the Canadian Financial Capability Survey, a program administered by Statistics Canada seeking to quantify the state of financial literacy in the country (Statistics Canada, 2010). Programs such as these ${ }^{9}$ are in keeping with a recent priority on part of the OECD to streamline and make comparable statistical data across countries relating to how different segments of the population far in terms of financial literacy (OECD, 2009). Here we see that there is increasingly an emphasis on discovering groups which are 'at risk' of making poor financial decisions based on their access (or lack thereof) to financial literacy training. It is important, though, not to understand this risk as an intrinsically real category, but rather a specific way of dealing with a set of problems surrounding, in this case, how people engage with the economy. Critically analyzing this

\footnotetext{
${ }^{8}$ In gaining access to these groups, the FCAC has partnered with over ten other government departments (e.g. Citizenship and Immigration, Indian and Northern Affairs Canada) through the Financial Literacy Committee which aids in the distribution of their learning tools (FCAC official, personal communication, Oct. 27, 2010).

${ }^{9}$ Similarly, the Canadian Council on Learning recently made available an online interactive map which allows users to compare numeracy and document literacy data across more than 52,000 neighbourhoods across the country in an effort to provide quantitative financial literacy data on a geographical level.
} 
risk lens has been a common practice among scholars seeking to make sense of the ways in which certain problems (e.g. insurance, crime) are framed and understood (see, for instance, O'Malley, 2009; Ewald, 1991). Because in this case the discovery and definition of risky populations seems to frame the deployment of this financial literacy mandate, looking at both the implications and assumptions of this style of probematization is crucial.

In primarily targeting these groups that haven't yet been exposed to financial literacy training, these programs are, at a very basic level, premised on the assumption that with the correct information, all financial consumers will be in a position to successfully navigate the modern financial marketplace. This is a vastly different approach than those preceding it as it doesn't actually seek to address the economic issues facing low-income borrowers, but rather assumes their decisions result from lack of financial literacy. By presenting groups such as Aboriginal Canadians, new immigrants, low-income families and young people as risky and in need of financial literacy training, this problematic disregards factors such as the household incomes of members of these groups or their access to mainstream financial institutions as being primary causal factors regarding the decisions they make. Posing the question in this way suggests that the choices that these individuals make are irrational - a product of their lack of knowledge rather than a product of their circumstances or respective positions within the economy. ${ }^{10}$

${ }^{10}$ Interestingly, one study (Buckland, 2010) which sought to look at whether low-income Canadians are in fact 'financially literate' found that many respondents had been quite successful at learning "to cope with strict budgets," had "constrained their credit," used a diverse set of activities to raise their income and were "reasonably knowledgeable about relevant government programs and banking services" (p. 357). The study found that where low-income individuals were facing obstacles, these weren't a product of "glaring financial illiteracy" but rather a combination of personal challenges and institutional 
By quantifiably measuring financial literacy across clusters of the population, we see the development of a statistical scientific knowledge base surrounding educational reasons why certain outcomes (e.g. high levels of credit card debt, the use of fringe financial services) are occurring, whereas previously people were assumed to be acting rationally given their circumstances. While previously the approach of government was to protect (through the regulation of interest rates, development of alternative credit options, etc.) individuals from the exploitation that could take place in the marketplace, today when one finds themselves in credit trouble, the responsibility for that hardship rests solely on the individual and the decisions they have made. This is, of course, provided they have been exposed to all the necessary information (i.e. financial literacy training) during the process. As one senior government bureaucrat at the FCAC stated, "our goal is to give them as much up to date and relevant information. That way...if they still decide to [use high interest lenders], at least they made an informed decision and they'll be fully conscious of the impact that going there will have" (FCAC official, personal communication, Oct. 27, 2010).

To gain a better understanding of the specific assumptions that are made when these issues of credit trouble are addressed within this financial literacy framework, one can look at the specific tools designed to promote literacy. For instance, if one looks closely at The City, it becomes clear that in attempting to market these tools to broad swaths of the population, the FCAC has perhaps overlooked some of the various ways in which different populations engage with the world of finance. By focusing on elements

factors such as the availability of financial services, declining wages and social assistance rates, and income-security policies which create a "welfare wall" (Buckland, 2010, p. 373). 
such as the importance of diversification of investments, how to calculate compound interest, the concept of risk vs. return, and different legal tactics designed to avoid paying income tax on investment income, this program fails in addressing many of the ways in which access to the world of finance is stratified across the population. Take for instance, the approach that The City takes when discussing fringe financial service. "These services are not closely regulated and often charge high fees," it suggests, "so you should use a regulated banking institution" (Government of Canada, 2010). While this advice is true and quite laudable, it fails to address the issues of financial exclusion - unbanked and underbanked populations - which the government's own studies have highlighted. The 2005 Survey of Financial Security, for example, which sought specifically to determine who is using services such as payday loans and for what reasons, found that low income families were fully twice as likely as non-low income groups to have used payday loans (Pyper, 2007, p. 7), that families with "little savings or no credit cards" were significantly more likely to have used them (Pyper, 2007, p. 12), that one sixth of payday loan users had sold an asset in the past to pay a debt and one fifth had dealt with a pawnbroker (Pyper, 2007, p. 10). In short, the government study found that many of the statistics indicate "a level of dire need" on part of payday loan users (Pyper, 2007, p. 10). Despite this data, the financial literacy approach of the FCAC seems to assume a universally rational and entrepreneurial financial consumer with a myriad of credit options who is simply using these services out of convenience. As one official put it, "we haven't been able to link a lack of credit with the payday loans...it doesn't seem to be a really bad thing as long as they know how much it's costing....and with payday lenders on every corner its very convenient" (FCAC official, personal communication, Oct. 27, 2010). 
When we compare this to the previous approaches discussed above, we see that the current financial literacy mandate is quite novel in its universal understanding of 'the consumer' as being homogenous unit in its relationship with the world of finance.

Evidently, there have been numerous changes in the way that government programs have imagined the relationship between the individual and the economy over the last century. The above analysis has highlighted how previously the government responsibilized citizens by recasting Victorian thrift in nationalist, rather than moral terms, how this was slowly eroded in the post-war period by Keynesian consumerist discourses, and the subtle ways in which these have laid the foundation for the quite distinct financial literacy approach of today. To further understand the current milieu in which the world of knowledge surrounding consumer credit exists, though, it is necessary to look not only at the government's approach to this problem, but also the way in which those who contest the importance of financial literacy understand these issues.

\section{Contesting Financial Literacy}

The discourse of community economic development gained prominence in the 1990s and since then interventions in the name of community have been commonplace in urban centres across Canada. In the area of fringe finance, these interventions have most often been spearheaded by large financial institutions and cooperative credit institutions such as credit unions. Buckland, in a survey of community banking projects (2008), identifies four examples of Canadian projects which have specifically sought to "offer...financial services for low-income people" (p. 3). These include: Pigeon Park Savings, a project started in 2004 by VanCity Credit Union that offers simple, low cost credit union accounts and services to residents of Vancouver's Downtown Eastside; 
Desjardins Credit Union's 'Mutual Assistance Funds' which offer low interest and no interest one time loans and financial counseling to credit union members facing financial trouble or who otherwise couldn't access credit; Royal Bank of Canada's 'Cash \& Save' program in inner-city Toronto, which offers low-fee cash checking to residents of depressed neighbourhoods; and finally, Winnipeg's Community Financial Services Centre which has been partnered with Assiniboine Credit Union since 2006 and seeks to offer financial services to those facing financial exclusion in Winnipeg's North End (Buckland, 2008, p. 7-8). While all of these projects may highlight different aspects of the ways in which the problem of community economic development is being presented by different parties in the banking sector, this chapter now turns to an in-depth analysis of the specifics of the Winnipeg case. The reason that the Winnipeg example was chosen for this analysis is because of a) the fact that in certain neighbourhoods of the city, mainstream banking sector contracted so dramatically in the 1990 s, creating a situation where fringe financial services could flourish and b) the fact that the project is an example of a unique trial partnership between community groups and a credit union and thus has been able to experiment with different services and approaches in developing and pursuing its mandate.

Today, in Winnipeg's North End, a neighbourhood with the lowest income statistics in the city, and a significantly higher unemployment rate than the rest of the city (see Buckland et al., 2003), numerous community development initiatives are present. One of the major issues that frames these interventions is that of 'financial exclusion' or the notion that because of bank closures during the 1990s in depressed urban centre, many are currently lacking access to mainstream financial institutions. It is argued that 
this has spawned the demand for fringe financial services such as cheque cashing outlets and payday loan shops.

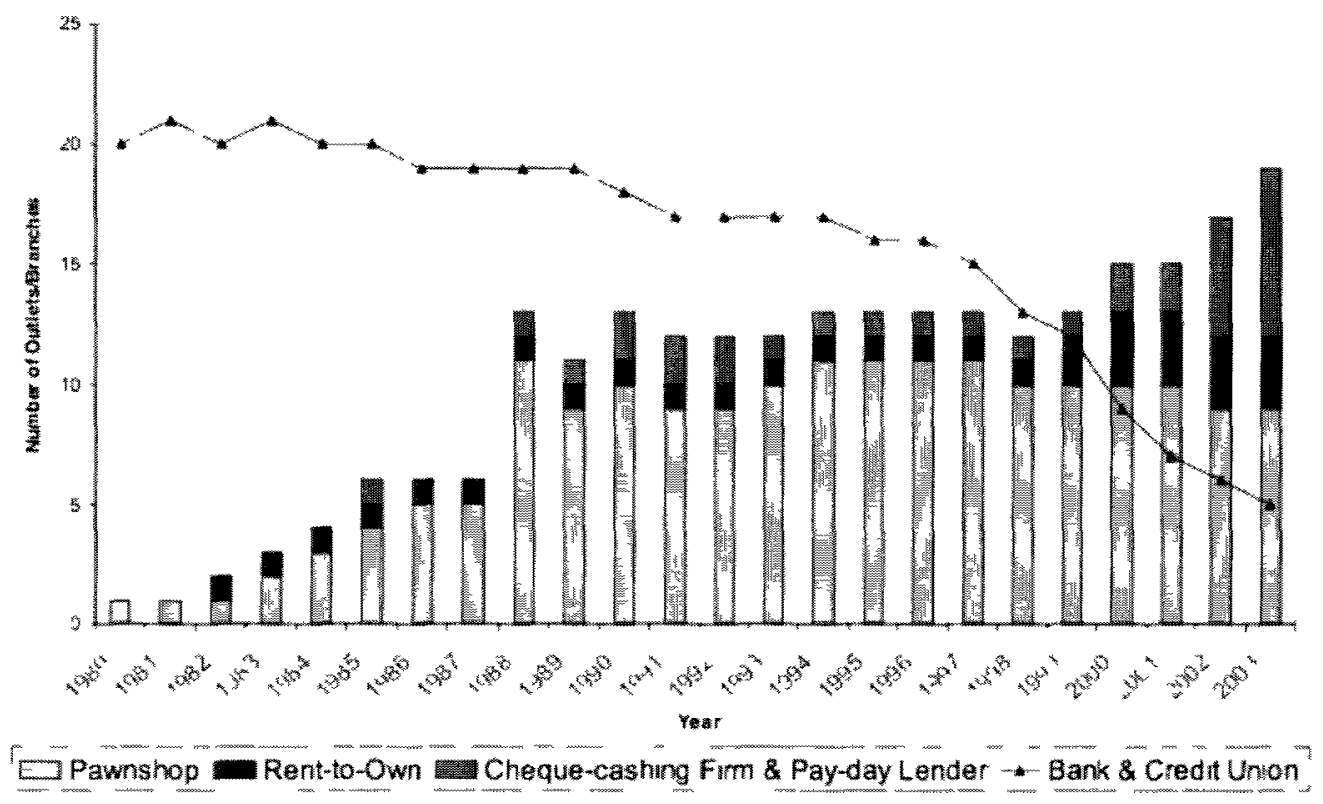

Source Wun peg lekphone Durstontes and Outer Follow up

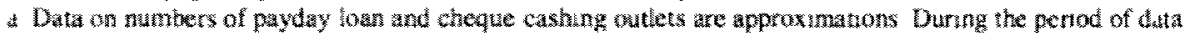

callectons the numbers aned consuderably wh we ones openng ip and some older ones clowng down

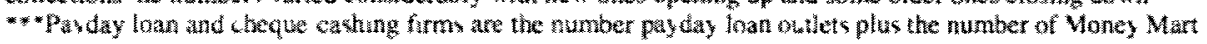

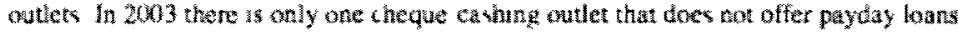

Figure 8: Number of Selected Fringe Financial Services and Mainstream Banks/Credit

Union Branches in Winnipeg's North End, 1980-2003. (From Buckland et al. 2003)

As one can see in the chart above, the closure of banks in the late 1990s and early 2000s

was accompanied by the opening of numerous rent to own, cheque cashing, and payday

loan outlets in the neighbourhood. This change in the financial landscape spawned the

development of the Alternative Financial Services Coalition, and the eventual opening in 2006 of the Community Financial Services Centre (CFSC), a partnership between

Winnipeg's largest credit union, Assiniboine (ACU), and the North End Community

Renewal Corporation (NECRC). The CFSC opened with the mandate of addressing the issues of financial exclusion in the neighbourhood and offering alternatives for those members of the community who are unable to access the services offered by mainstream 
financial institutions. "We target low income families," on CFSC employee articulates, "those people who are using pawnshops, fringe financial institutions, payday loans, any of those places that are getting rich off of the poor" (personal communication, Nov. 12, 2010).

In attempting to address these issues, the primary tool that the CFSC has used is making people 'account ready' and helping them build a relationship with an accessible mainstream financial institution so that they will have access to more affordable financial services such as cheque cashing, money transfers and credit. A major barrier that they found in researching this problem was identification requirements which are necessitated by mainstream banks; many in the neighbourhood didn't have the necessary two pieces of government ID necessary to open an account. As such, in partnership with the ACU and nineteen community organizations, the CFSC set up a referral system wherein clients of North End outreach organizations can be referred to the CFSC and use the referral letter from those partner organizations as the basis on which to create an ACU account at the CFSC. While at the CFSC setting up the account, clients are given a CFSC member ID which they can use in future dealings with the organization.

Perhaps the greatest benefit to customers comes in the type of account that ACU offers CFSC clients. Because this initiative has as a guiding principle the desire to aid an economically depressed population, the accounts have no monthly fees and no holds on government cheques nor cheques from the organization that referred the client to the CFSC. With over 530 members right now, this has resulted in thousands of dollars in fees saved by members and furthermore lessened their reliance on cheque cashing outlets which typically charge a flat fee per $\$ 100$ to cash cheques (CFSC, 2010). 
By specifically targeting 'financially excluded' populations, and implicitly assuming a marginalized subject in the design of programming, the CFSC has been able to address many of the barriers which typically keep low-income consumers away from mainstream financial institutions and in the world of fringe finance. This is reflected in the targeted programs above to overcome the identification difficulties that many lowincome groups have when trying to open an account, but also in the attempts on part of the CFSC and ACU to address the issues of stigma which often affect the interface between marginalized groups and the mainstream financial world. One way in which this has been addressed was by not actually creating a new type of account for CFSC clients, but rather modifying a regular account with the no fee provisions. This way, when a CFSC client enters a regular ACU branch, there will be no automatic identification of them as a CFSC client when they speak to a teller.

Once you become a [CFSC] member in an account where all the fees are waved you can come back and apply for credit, you can get American money, wire money, do all the transactions that everyone else can. If they would like to come in, fly under the radar and not identify themselves, no one will know and they'll be treated just as any other member would. (ACU official, personal communication, Nov. 15, 2010)

The sensitive way in which this program understands its marginalized clientele is further reflected in the comments made by a senior ACU official regarding the position of financial literacy training within the project:

Financial literacy is obviously a huge component of what we're doing at the CFSC, but I don't think it's as large a component as some people make it out to be. People that are using fringe financial services aren't necessarily people who don't know anything about financial institutions. They know what they're paying, they're not stupid. 
They're paying because it's convenient and because they don't have other options available to them. Forcing people to sit through ten weeks of financial literacy training is very paternalistic and doesn't need to be part of the model. What you need to do is be convenient, offer services, not stigmatize, and do all of that in a way that's sustainable. (ACU official, personal communication, Nov. 15, 2010)

Thus, by both acknowledging the factors which shape the interface between finance and the consumer across different segments of the population, yet also being conscious of issues of stigma and paternalism, the CFSC project is attempting to offer a much more nuanced understanding of the issues associated with fringe finance than that of the government's current responsibilization scheme. This approach echoes much of the political debate which surrounded government responsibilization in previous eras, as articulated above, such as the universality of the consumer subject and the different role that credit plays in the lives of the poor.

While the CFSC began as just a pilot project, its success has spawned a commitment on part of the ACU to open a branch in the North End and thus extend its services to a greater portion of the North End population. While the project hasn't been a revenue generator for $\mathrm{ACU}$, it fits into the organizations mandate of thinking about how its actions "will impact the community in which [they] do business" (ACU, 2010).

The reason we're doing this is because it meets a core goal of ours which is supporting community renewal, strengthening Winnipeg, and reducing poverty. That's why we're there; it's certainly not a revenue generator for us by any stretch of the imagination. The amount of time we sink into it...I can't exactly tell you how much because that's not how we measure these things. It's just part of how we do business; it's incorporated into our profit loss across the entire organization. (ACU official, personal communication, Nov. 15, 2010)

The CFSC is just one of ACU's many 'building sustainable communities' initiatives and 
is reflective of the social role that the organization sees itself as playing. As a financial cooperative, the organization seeks to leverage the savings of members to "foster selfreliant and sustainable communities" (ACU, 2010). In discussing the role the credit unions can play compared to that of the fringe finance sector, one ACU official did not understate the role that credit unions can play in mobilizing capital for both community reinvestment and credit for low-income groups:

There is a broader community aspect here in terms of the money that leaves a neighbourhood when people conduct their business at a fringe financial institution. Those are typically not owned by people within the community and the profits are being siphoned away. Every dollar that goes in there is a net loss to the neighbourhood. You can look at a credit union coming into a neighbourhood and see that it's a net benefit. A branch of ours will leverage dollars and assets from outside of the neighbourhood and lend it internally so that there can be some community development at affordable rates. You're bringing outside capital in if someone wants to start a business or something like that and the outside capital helps to develop the neighbourhood...there's a whole community economic development aspect to this whole thing. (ACU official, personal communication, Nov. 15, 2010)

By posing the issue of community reinvestment in this way, $\mathrm{ACU}$ is calling upon its members to allow the organization to use their personal savings for a social good. By mobilizing discourses of ethical investment in this way, equating the value of saving with activism vis-à-vis thoughtful investment, ACU draws on notions of an active, socially responsible consumer that was very prevalent in War Thrift campaigns eighty years ago. By reposing the 'consumer' as a 'member' and specifically politicizing savings as a communal form of community investment, credit unions assume a markedly different relationship between the individual and the economy than do current financial literacy discourses. 
Scholars such as Rose (1996) suggest that the heterogeneous lens of 'community' is displacing the 'social' territorialization through which we have approached many of our problems in previous eras. As the above analysis begins to make clear though, it is important both not to read this as strictly a neoliberal shift, nor to understand this in terms of an dramatic periodization. While, on the one hand, government programming in recent decades has begun to constitute its subjects as autonomous, sovereign, responsible consumer investors, non-governmental actors such as credit unions have been, at the same time, responding to the effects of this and seeking to address the issues associated with access to affordable credit among marginalized populations. This is in keeping with the work that these institutions have been doing for over one hundred years in Canada. Today, their community reinvestment and financial exclusion programming redeploys historical discourses of thrift and social obligation and stand as a very poignant and politically charged contestation of the knowledge base on which both financial literacy as a tool and the legitimacy of fringe financial institutions sit. By using communally saved funds to provide affordable financial services to those currently affected by the fringe finance sector, programs such as those elaborated above politicize the current consumerist approach of the government and highlight the ways in which different populations are affected in markedly different ways by the burgeoning quasi-financial world. While the liberalizing rationality of government programming may be increasingly based on the imaginary of heterogenous "communities with incompatible allegiances and incommensurable obligations," socializing programming like that outlined above continues to persist, responding to the negative effects of this liberalization. 
This chapter has attempted to give some sense of both the novelty of the government's current financial literacy mandate and the ways in which it reflects a long history of responsibilization programming. While the universal assumption of the consumer subject within this approach is novel, the consumerist foundations on which it is built have been within the discourse surrounding responsibilization programs since the inter-war period. Furthermore, programs which currently try to address the issues associated with fringe finance by credit unions, couched in community economic development and financial exclusion discourses, draw on a long history of contestation regarding the relationship between marginalized groups and economic responsibility in their politicization of the financial literacy mandate. Furthermore, they draw heavily on relationship between individual savings and communal good that was solidified in government programs promoting war thrift. 


\section{Conclusion}

It is my hope that the preceding three chapters have displayed the nuance, precariousness and complexity of the payday loan as it exists today as a modern financial service. In Chapter I, it was shown that while previously, usury was seen by regulators as an inherently immoral practice which threatened a marginalized class of individuals unable to protect themselves, payday lending today it is presented as a legitimate financial service which effects sovereign and rational 'financial consumers'. Chapter II showed that the event of the payday loan is constituted through practice as a similarly modern consumer convenience, distancing itself from analogous practices of the past such as pawnbroking. At the same time though, it is dependent on many of the same coercive collection tactics that previous usurers, such as loan sharks employed. Chapter III, finally, sought to trace the emergence of 'financial literacy' as the primary tool by which government seeks to regulate this practice. It showed that this approach, based on a universalist understanding of how fringe finance effects 'consumers' is a major departure from previous regulatory approaches such as the thrift ethic and serves to overshadow many of the specific and complex difficulties that people on the margins of the economy face. Furthermore, it showed that there are indeed non-governmental projects taking markedly different approaches to the issue, highlighting many of the problems that 'financial literacy' seems to obscure.

Taken as a whole, this project has tried to accomplish two things - one practical, and one theoretical. On a practical level, I have tried to critically examine the rise of the payday loan and the ways in which it is currently being regulated, thus laying the foundation for an engaged political discussion on the issue. In exploring parliamentary 
debates on usury as well as the actual practices of lending and collecting themselves, I hope to have shown the never before has this type of lending been so widely accepted as legitimate. Further, by exposing some of the illiberal aspects of payday lending (e.g. collections practices) and highlighting some of the consistencies that the sector has with the usurious practices of past eras, I hope to have shown the novelty regarding how we currently engage with the sector as a part of the financial industry. There are indeed political implications when something which was previously understood as dubious and dangerous to marginalized members of society comes into the legitimate consumerist public sphere so quickly; discussion of its morality and who it effects take on a different, more liberal character. I hope to have highlighted this.

By exposing the assumptions that the government is making in its financial literacy mandate, I hope to have laid a foundation on which a debate on this issue could similarly occur. When we envision the payday lending problem as primarily one of financial literacy, a number of assumptions are being made about who payday loans effect, why people get into trouble with payday lenders, and why the sector has been so successful in recent decades. In this case, the problem is apriori posed as one of 'lack of knowledge' rather than one of exploitation, as was the case when we thought about analogous historical practices. Similarly, when the thrust of government activity and research is focused on increasing financial literacy, people often neglect to look at other avenues (e.g. regulation, the support of alternative credit options) that may be taken to lessen the negative effects of the sector. It is my hope that this thesis made these points clear by showing both the history and effects of both the practices of usury and their historical regulation. 
Finally, by exploring the terms on which community groups and credit unions are currently contesting this issue, I hope to have highlighted what is currently being done by non-governmental actors to mitigate some of the negative effects of fringe finance. I hope that this examination has lent support to these various community actors and shown that there are real alternatives to payday lending which seek to address the needs of borrowers while at the same time acknowledging in a reflexive way some of the structural, political and economic issues which perpetuate the growth of the sector. In doing so, these lenders are able to design products which are both attractive to borrowers yet don't perpetuate some of the negative outcomes (e.g. chronic indebtedness, high interest rates) that payday lending seems to have contributed to.

At the theoretical level, it is my hope that this examination of payday lending has helped to highlight the importance of discourse and ideas in the complex process of historical change. At a very basic level, I have tried to show that the payday loan does not exist today as a legitimate and legal entity due to anything as grand as ideology or a neoliberal burgeoning of the financial world. Rather, its emergence results from the nonintentional overlapping of numerous subtle changes. The knowledge bases regarding usury, its subjects, morality, economy and the poor have undergone shifts and transformations that have at a very foundational level, altered the terrain on which this problem sits.

These shifts have been ideational and material. For example, who we understand usury to effect has undergone significant transformation as class has faded away as the primary intellectual tool by which we divide society and thus assign responsibility. This has served to reshape the moral economy on which the issue of usury rests; when high 
interest lending no longer impacts a marginalized class of individuals who are unable to protect themselves, it becomes more difficult to deem the practice as universally exploitative. This has happened at the same time as our notion of what it means to be a responsible economic citizen has changed; the ethic of thrift has disappeared, credit has been normalized, and financial literacy has concomitantly emerged as a main governing force in how we make sense of these problems. With this financial literacy mandate, the problems previously associated with the negative effects of usury are transformed into a new problem-set surrounding a lack of education and knowledge. Consumers - a now homogenous category - are understood as more autonomous and expected to act 'rationally' within a market system, regardless of the nuances and constraints associated with their economic position. These changes have occurred at the same time as the very material practices of high-interest lending themselves have undergone significant transformation, altering in a very immediate way the way in which we make sense of and visualize the problem of high-interest lending. What was previously understood and presented as a service that specifically targets those in desperate need has been reconstituted with the payday loan as a modern consumer convenience; it has been brought into the public realm and made to look professional, welcoming and safe. All of these changes - economic, material, ideational, and moral - have come together to fundamentally alter the tools - the intellectual signifiers, divisions and representations that we use to create and make sense of the 'problem' of the payday loan today. These changes, these discoveries and these inventions have built the foundation on which we engage with this problem. Looking at all of this volatility together, it begins to become clear that knowledge is quite simply at the heart of the complex process of historical 
change. Above all, it is this - the power inherent in our ways of knowing - that this thesis has tried to highlight. 


\section{Appendix}

\section{I) Letter to Collection Agencies from Ontario Ministry of Small Business and Consumer Affairs}

\author{
Ministry of \\ Small Business and \\ Consumer Services
}

Debt Recowery Regulation Unt

Consumer Protecton Branch

5775 Yonge Street, Suite 1500

Toronto ON M7A 2E5

Tel 416326.8802

Toll-ree: $1800889-9768$

Fax: 4163268810

Registrar of Collection Agencies

27 October 2008

\author{
Ministère des Petites Entreprises \\ et des Services aux \\ consommateurs
}

Unité de la reglementation du recouvrement des dettes

Direction de la protection du consommateur 5775 , rue Yonge, bureau 1500

Toronto ON M7A ZE5

Tht. : $416326-6203$

Sans frais: $1800889-9768$

Telec. : $416326-9810$

To Collection Agoncies per the attached list

Re: Use of "draft" statements of claim' lawyers letters

I wish to address two issues with you, as the reference line would suggest. The first is the practice of including a "draft" statement of claim with demand letters; the second is the sending of demand letters purportedly from lawyers without reference to the collection agency. I have received complaints about these practices from both debtors and collection agencies.

The first issue is that of including "draft" statements of claim with demand letters. I am not going to cloud this issue dealing with questions like whether the agency has the authority from its client to sue, or whether the limitation period for commencing an action has passed. Those questions go to the propriety of commencing an action not the propriety of sending a "draft" statement of claim to a debtor.

In my mind therc can be no other reason to send a "draft" statement of claim than in the hope that it will lend more credence to the agency's assertion that failure to pay may result in the commencement of an action and therefore elicit payment. The practice trades on the expectation that debtors will be unknowledgeable about court process and interpret the "draft" statement of claim as a greater commitment to pursuing the matter in court than actually exists; it relies on debtors not recognizing that the document enclosed with the demand letter is little more than boiler plate with little investment in time and thought. In my opinion, if this was not the case agencies would simply threaten to sue if payment was not received, and issue and scrve a statement of claim if payment was not forthcoming. Accordingly $I$ believe the practice of enclosing a "draft" statement of claim is both deceitful and misleading.

Subsection 2 of section 21 of the Collection Agencies Act provides me with the authority to order that letters, forms and the like that I believe are misleading or deceitful to not be uscd. This is not an order, but is advice that I find the practice objectionable for the reasons set out and therefore require it to stop. Further complaints respecting this matter will result in an order directed to the agency involved. 
I would also draw your attention to the provisions of the Debt Collectors Act, RSO 1990, Chapter D4. which creates the offence of using imitations of court forms. I would argue that the provision is applicable to the circumstance discussed here. Irrespective of whether you agree, I think the provision is instructive of a public policy that frowns on the use of court forms for other than their intention; the actual commencement and prosecution of an action.

The second matter is that of demand letters sent by lawyers retained by collection agencies. In the samples of the letters I have received, the lawyer fails to indicate by whom they have been retained, but simply state that a debt is owed to a particular creditor. The letter then goes on to speak of a statement of claim having been drafted and that an action may be commenced if payment is not received, in some instances "draft" statements of claim are included. For the same reasons as stated above I find this practice to be deccitful and misleading, doubly so because of the inference that a lawyer is involved. Where a lawyer does something on behalf of a collection agency it is no different, as far as I am concerned, than the agency doing it itself. The practice of entering into an arrangement with a lawyer, whether as employee or on a fee for service basis, to send letters without an indication that the agency has retained their services for that purpose and permitting the lawyer to enclose with their letter a "draft" statement of claim is to cease. Failure to heed this advice will result in the issue of an order and the taking of such enforcement measures as necessary to obtain compliance.

1 am aware that the use of "draft" statements of claim was common in the past and thought that it was relegated to the past. Unfortunately that does not seem to be the case and consequently this letter. So that everyone is on an equal footing you now have my position on the questions and my expectation. If you are an agency that indulges in either of the practices, I ask that you cease and no more will be said.

Should you wish to discuss this matter, or any other, please don't hesitate to contact me.

Yours truly

Brian Pitkin, CD

Registrar

2 of 2

pitkin/ca/"draft statements of claim 


\section{Works Cited}

Abbott, Berenice (Photographer). (1938). Rothman's Pawn Shop. Retrieved December 1, 2009 from Museum of the City of New York website. http://www.mcny.org/

Aitken, R. (2010). Regul(ariz)ation of Fringe Credit: Payday Lending and the Borders of Global Financial Practice. Competition and Change, 14(2), 80-99.

Aitken, R. (2006). Capital at its fringes. New Political Economy, 11(4), 479-498.

Alighieri, Dante. (1883). The Inferno of Dante. Longman.

Alternative Consumer Credit Market Working Group. (2002). Consultation Paper on Framework Options for Addressing Concerns with The Alternative Consumer Credit Market. Retrieve from the Consumer Measures Committee website: http://www.ic.gc.ca/eic/site/cmccmc.nsf/vwapj/CMC_credit_e.pdf/\$FILE/CMC_credit_e.pdf

Althusser, L. (2005). For Marx. New York: Verso.

Arendt, H. (1998). The Human Condition. University of Chicago Press.

Assiniboine Credit Union. (2010). About Us. Retrieved from: http://www.assiniboine.mb.ca/My-Assiniboine/About-Us.aspx

Barr, M. (2004). Banking the poor. Yale Journal on Regulation. 21(121), 220-237.

Bauman, Z. (2005). Work, Consumerism and the New Poor. McGraw-Hill International.

Bellamy Foster, J. (2006). The household debt bubble. Monthly Review, May 2006, 1-11.

Bentham, J. (1816). Defense of Usury. Payne and Foss.

Birkhead, J. B. (1941). Collection Tactics of Illegal Lenders. Law and Contemporary Problems, 8(1), 78-87.

Blankenhorn, D., Whitehead, B. D., \& Brophy-Warren, S. (2009). Franklin's Thrift: The History of a Lost American Virtue (1st ed.). Templeton Press.

Botterill, J. (2010). Consumer Culture and Personal Finance: Money Goes to Market (1st ed.). Palgrave Macmillan. 
Brook, D. (2009, April). Usury country; welcome to the birthplace of payday lending. Harpers Magazine, 41-48.

Bröckling, U., Krasmann, S., \& Lemke, T. (2011). Governmentality: Current Issues and Future Challenges. Taylor \& Francis.

Buckland, J., Martin, T., Barbour, N., Curran, A., Mcdonald, R., \& Reimer, B. (2003).

The Rise of Fringe financial Services in Winnipeg's North End: Client Experiences, Firm Legitimacy and Community Based Alternatives. Retrieved from: http://ius.uwinnipeg.ca/WIRA/wira_pub-fringe-financial.htm

Buckland, J., Martin, T. (2005). Two-Tier Banking: the Rise of Fringe Banks in Winnipeg's Inner City. Canadian Journal of Urban Research, 14(1).

Buckland, J., Carter, T., Simpson, W., Friesen, A. \& Osborne, J. (2007). Serving or Exploiting People Facing a Short-term Credit Crunch? Aspects of Payday lending in Manitoba. Report for the 2007 Public Utilities Board Hearing to Cap Payday Loan Fees. Retrieved from: http://geograph.uwinnipeg.ca/Carter/Publications/Journals/Serving-Exploiting.pdf

Buckland, J. (2008). Community banking projects for low-income Canadians: a report examining four projects to promote financial inclusion. Retrieved from: http://ssrn.com/abstract $=1585804$

Buckland, J. (2010). Are Low-Income Canadians Financially Literate? Placing Financial Literacy in the Context of Personal and Structural Constraints. Adult Education Quarterly, 60(4), 357.

Business Wire. (2011). Dollar Financial Corp. announces record third quarter results. Retrieved from: http://eon.businesswire.com/news/eon/20110428007039/en

Canada. Parliament. House of Commons. (1906, April 6). Debates, $10^{\text {th }}$ Parliament, $2^{\text {nd }}$ Session.

Canada. Parliament. House of Commons. (1906, March 20). Debates, $10^{\text {th }}$ Parliament, $2^{\text {nd }}$ Session.

Canada. Parliament. House of Commons. (1939, April 25). Debates, $18^{\text {th }}$ Parliament, $4^{\text {th }}$ Session.

Canada. Parliament. House of Commons. (1939, April 26). Debates, $18^{\text {th }}$ Parliament, $4^{\text {th }}$ Session.

Canada. Parliament. House of Commons. (1974, November 1). Debates, $30^{\text {th }}$ Parliament, $1^{\text {st }}$ Session. 
Canada. Parliament. House of Commons. (1974, November 1). Debates, $30^{\text {th }}$ Parliament, $1^{\text {st }}$ Session.

Canada. Parliament. House of Commons. (1976, November 2). Debates, $30^{\text {th }}$ Parliament, $2^{\text {nd }}$ Session.

Canada. Parliament. House of Commons. (1976, November 3). Debates, $30^{\text {th }}$ Parliament, $2^{\text {nd }}$ Session.

Canada. Parliament. House of Commons. (1976, November 4). Debates, $30^{\text {th }}$ Parliament, $2^{\text {nd }}$ Session.

Canada. Parliament. House of Commons. (1979, November 14). Debates, $31^{\text {st }}$ Parliament, $1^{\text {st }}$ Session.

Canada. Parliament. House of Commons. (1979, November 26). Debates, $31^{\text {st }}$ Parliament, $1^{\text {st }}$ Session.

Canada. Parliament. House of Commons. (1980, July 21). Debates, $32^{\text {nd }}$ Parliament, $1^{\text {st }}$ Session.

Canada. Parliament. House of Commons. (2006, October 24). Debates, $39^{\text {th }}$ Parliament, $1^{\text {st }}$ Session.

Canada. Parliament. House of Commons. (2007, February 5). Debates, $39^{\text {th }}$ Parliament, $1^{\text {st }}$ Session.

Canada. Parliament. Senate. (1900, May 14). Debates, $8^{\text {th }}$ Parliament, $5^{\text {th }}$ Session.

Canada. Parliament. Senate. (1900, May 8). Debates, $8^{\text {th }}$ Parliament, $5^{\text {th }}$ Session.

Canada. Parliament. Senate. (1939, March 30). Debates, $18^{\text {th }}$ Parliament, $4^{\text {th }}$ Session.

Canada. Parliament. Senate. (1939, March 30). Debates, $18^{\text {th }}$ Parliament, $4^{\text {th }}$ Session.

Canadian Payday Lending Association. (2011). Welcome. Retrieved online from: http://www.cpla-acps.ca/english/home.php

Cash Money. (2009). What You See is What You Get. Retrieved November 25, 2009 from Bank Street Cash Money, Ottawa, Ontario.

Cash Money. (2010). Payday Loans. Retrieved October 20, 2010 from Bank Street Cash Money, Ottawa, Ontario.

CashNet USA. (2009). Retrieved December 1, 2009 from http://www.cashnetusa.com 
Cash Store Financial. (2010). Annual Report 2010. Retrieved from:

http:/www.csfinancial.ca/Libraries/Corporate_Information/Annual_Report_FINAL PRINTED_Dec_14_3pm.sflb.ashx

Caskey, J. \& Zikmund, B. (1990). Pawnshops: The consumer's lender of last resort. Economic Review, 5-18.

Caskey, J. (1994). Fringe Banking: Cash-checking outlets, pawnshops, and the poor. New York: Russell Sage Foundation.

Caskey, J. (2005). Fringe banking and the rise of payday lending. In P. Bolton \& H. Rosenthal (eds.), Credit Markets for the Poor. (pp. 17-45). New York: Russell Sage Foundation.

Collection Agencies Act, R.S.O. 1990, c.14.

Complaints Board. (2010). The Cash Store complaints: overpriced and misleading. Retrieved from: http://www.complaintsboard.com/complaints/the-cash-storec295210.html

De Goede, M. (2005). Virtue, Fortune, and Faith: A Genealogy of Finance. Minneapolis: University of Minnesota Press.

De Roover, R. (1948). Money, Banking and Credit in Medieval Bruges: Italian Merchant Bankers, Lombards and Money-Changers, A Study in the Origins of Banking. Cambridge.

Dean, M. (1992). A genealogy of the government of poverty. Economy and Society, 21(3), 215-251.

Dean, M. (1999). Governmentality. Sage Publications.

Dean, M. (2009). Governmentality: Power and Rule in Modern Society (Second Edition.). Sage Publications Ltd.

Defoe, D. (1719). Robinson Crusoe. W. Taylor.

Dickens, C. (1835, June). Sketches of London No. 35. Evening Standard. Retrieved from: http://charlesdickenspage.com/pawnbrokers.html

Dollar Financial Corp. (2011). Welcome. Retrieved from: http://www.dfg.com/default.asp

Donzelot, J. (1979). The policing of families. Random House Inc.

Donzelot, J. (1988). The promotion of the social. Economy and Society, 17(3), 395-427. 
Dransford, R. (Writer \& Director). (2009). Broke [Film]. Canada.

Du Gay, P. (1996). Consumption and identity at work. Sage Publications Ltd.

Easy Online Payday Loan. (2009). Retrieved from:

http://www.easyonlinepaydayloan.com/

Elliehausen, G. \& Lawrence, E. (2001). Payday Advance Credit in America: An Analysis of Customer Demand. Washington: Georgetown University.

Ernst, K., Farris, J., King, U. (2003). Quantifying the Economic Cost of Predatory Payday Lending. Centre for Responsible Lending. Retrieved from: http://cfsinnovation.com/system/files/imported/managed_documents/crlpaydaylend ingstudy.pdf

Erturk, I., Froud, J., Johal, S., Leaver, A., \& Williams, K. (2007). The democratization of finance? Promises, outcomes and conditions. Review of International Political Economy, 14(4), 553-575.

Ewald, F. (1991). 'Insurance and Risk' in G. Burchell, C. Gordon \& P. Miller (Eds.), The Foucault Effect: Studies in Governmentality (pp. 197-210). Chicago: University of Chicago Press.

FAIR Canada. (2009). Ontario government introduces financial literacy in school curriculum. Retrieved online from: http://faircanada.ca/dialogue/ontariogovernment-introduces-financial-literacy-in-school-curriculum/

Fassin, D. (2005). Compassion and repression: the moral economy of immigration policies in France. Cultural Anthropology, 20(3), 362-387.

Financial Consumer Agency of Canada. (2008). The Financial Consumer Agency of Canada and the B.C. Securities Commission bring financial life skills training to Canadians. Press Releases. Retrieved from: http://www.fcacacfc.gc.ca/eng/media/news/default.asp?postingId $=254$

Financial Consumer Agency of Canada. (2010). Mandate. Retrieved online from: http://www.fcac-acfc.gc.ca/eng/about/role/default.asp

Flaherty, J. (2009, June 26). Task Force on Financial Literacy. Speech presented at the Sheraton Centre, Toronto, Ontario.

Flannery , M.J. \& Samolyk, K. (2005, June). Payday lending: Do the costs justify the price? FDIC Center for Financial Research Working Paper No. 2005/09. Retrieved from SSRN: http://ssrn.com/abstract $=771624$ 
Fogarty, M. (2011, Feb. 14). Payday lenders 'using Tribes as fronts.' Indian Country Today Media Network. Retrieved from:

http://indiancountrytodaymedianetwork.com/2011/02/payday-lenders-'using-tribesas-fronts'/

Foucault, M. (1977). Nietzsche, genealogy history. In D. Bouchard (ed.) Language, Counter-Memory, Practice: Selected Essays and Interviews, pp.139-164. Ithaca: Cornell UP.

Foucault, M. (1978). The History of Sexuality: An introduction. Pantheon Books.

Foucault, M. (1995). Discipline \& Punish. Random House of Canada.

Foucault, M. (2006). Archaeology of Knowledge. Routledge.

Foucault, M. (2007). Security, Territory, Population. Palgrave Macmillan.

Foucault, M., Rabinow, P., \& Rose, N. (2003). The Essential Foucault. New Press.

Foucault, M., \& Rabinow, P. (2006). Ethics: Subjectivity and Truth (1st ed.). New Press.

Gibson-Graham, J. K. (2006). A Postcapitalist Politics. U of Minnesota Press.

Gilbert, John (Illustrator). (1862). Inside the Pawnshop. Retrieved from the Database of Mid-Victorian wood-engraved Illustration. http://www.dmvi.cf.ac.uk

Government of Alberta. (2009). Alberta Government protects payday loan customers. Retrieved from: http://alberta.ca/home/NewsFrame.cfm?ReleaseID=/acn/200906/26139A6EB8458F10F-2F84-66326AA515D86A9D.html

Government of British Colombia. (2009). Government moves to regulate payday lenders. Retrieved from: http://www2.news.gov.bc.ca/news_releases_20052009/2009PSSG0022-000255.htm

Government of Canada. (2010). The City. Retrieved from: http://www.themoneybelt.gc.ca/theCity-laZone/eng/login-eng.aspx

Government of Manitoba. (2010). New payday loans rates and rules proclaimed. Retrieved from: http://news.gov.mb.ca/news/index.html?archive=2010-7$01 \&$ item $=9269$

Government of Nova Scotia. (2011). Payday loans. Retrieved from: http://www.gov.ns.ca/snsmr/access/individuals/consumer-awareness/consumerloans-credit/payday-loans.asp 
Government of Ontario. (2009, Feb. 6). Capping Borrowing Costs: A Balanced Approach to Payday Loans in Ontario. Retrieved from:

http://www.sse.gov.on.ca/mcs/Documents/264305.pdf

Government of Ontario. (2010). Ontario protects payday loan users. Retrieved from: http://news.ontario.ca/mcs/en/2009/03/ontario-protects-payday-loan-users.html

Government of Saskatchewan. (2010). Payday loans regulations - fact sheet. Retrieved from:

http://www.gov.sk.ca/adx/aspx/adxGetMedia.aspx?mediaId=1159\&PN=Shared

Guttmann, R. (2008). A primer on finance-led capitalism and its crisis. Revue de la Régulation, 3(4).

Hacking, I. (2004). Historical Ontology. Cambridge: Harvard University Press.

Harmes, A. (2001). Mass investment culture. New Left Review 9, 103-124.

Harvey, D. (1990). The Condition of Postmodernity. Oxford: Blackwell.

Hunt, A., \& Wickham, G. (1994). Foucault and the Law. Pluto.

Is thrift dangerous? (1943, Nov. 2). Ottawa Citizen, p. 22.

Johnson, R. \& Johnson, D. (1998). Pawnbroking in the U.S.: A Profile of Customers. Washington: Credit Research Center.

Kaplan, L. J., \& Matteis, S. (1968). The Economics of Loansharking. American Journal of Economics and Sociology, 27(3), 239-252.

Kirchhoff, S. (2006, Sept. 9). Breaking the cycle of the payday loan 'trap'. USA Today. Retrieved December 1, 2009 from http://www.usatoday.com/money/perfi/general/2006-09-19-credit-unionsusat_x.htm

Kitching, A. \& Starky, J. (2006). Payday Loan Companies in Canada: Determining the Public Interest. Government of Canada: Parliamentary Information and Research Service.

Kleinfield, N. (1989, August 13). Running the little man's bank. New York Times. Retrieved from: http:/www.nytimes.com/1989/08/13/business/running-the-littleman-s-bank.html 
Langley, P. (2007). Uncertain subjects of Anglo-American financialization. Cultural Critique, 65, 67-91.

Langley, P. (2008). Financialization and the consumer credit boom. Competition \& Change, 12(2), 133-147.

Lemke, T. (2001). 'The birth of bio-politics': Michel Foucault's lecture at the Collège de France on neo-liberal governmentality. Economy and society, 30(2), 190-207.

Lemke, T. (2002). Foucault, governmentality, and critique. Rethinking Marxism, 14(3), 49-64.

Management Today. (1991, January). The redemption of the pawnbroker. Management Today.

Marcuse, H. (1991). One-Dimensional Man: Studies in the Ideology of Advanced Industrial Society. Beacon Press.

Mayer, R. (2003). Payday Loans and Exploitation. Public Affairs Quarterly, 17(3), 197217.

Miller, P. \& Rose, N. (1997). Mobilizing the consumer: assembling the subject of consumption. Theory, Culture \& Society, 14(1), 1-36.

Miller, P. \& Rose, N. (2008). Governing the Present: Administering Economic, Social and Personal life. Polity.

Ministry of Finance of Canada. (Creator). (1918, Sept. 30). Say No!. [Advertisement]. Toronto World.

Money Belt. (2010). About the Money Belt. Government of Canada. Retrieved online from: http://www.themoneybelt.gc.ca/belt-clik-eng.asp

Money Mart Brochure. (2009). Retrieved November 25 from Bronson Ave. Money Mart, Ottawa, Canada.

Mr. Payday. (2011). Terms and conditions. Retrieved from: http://www.mrpayday.ca/terms.shtml

National Committee Victory Loans. (Creator). (1939-1945). [Digital Image]. Library and Archives Canada.

National Council of Women. (1951). Why Be Thrifty?

National Union of Public and General Employees. (2010). Scavengers in the debt crisis: payday loans. Smart Money. Retrieved from: 
http://nupge.ca/files/images/pdf/Scavengers\%20in\%20the\%20Debt $\% 20 \mathrm{Crisis} \% 20 \mathrm{P}$ ayday\%20Loans.pdf

Night Hawk. (1829, July 4). No. XXVII. Mechanics Free Press, Philadelphia.

Nugent, R. (1941). Loan-Shark Problem, The. Law \& Contemp. Probs., 8(3), 3-13.

O'Malley, P. (2008). Governmentality and Risk. Retrieved from:

http://papers.ssrn.com/sol3/papers.cfm?abstract_id=1478289

OECD. (2009). Framework for the development of financial literacy baseline surveys: a first international comparative analysis. OECD Working Papers on Finance, Insurance and Private Pensions No. 1. OECD Publishing.

Ontario Department of Education. (1919). The Thrift Campaign in the Schools of Ontario with a Brief Sketch of what Ontario has Done in the War. Government of Ontario: Toronto.

Ontario Ministry of Education. (2011). Financial Literacy. Retrieved from: http://www.edu.gov.on.ca/eng/surveyLiteracy.html

Ottawa booklet tells of pitfalls. (1970, Oct. 13). The Montreal Gazette, p. 29.

PWC. (2011). Perspectives on the Canadian Banking Industry. Retrieved from: www.pwc.com/ca/canadianbanks

Paterson, C. (2008). Usury law, payday loans, and statutory sleight of hand: Salience distortion in American credit pricing limits. Minnesota Law Review, 92, 1110-1165.

Paulin v. P.C.M. Collections (2008). CanLii 732 (ON S.C.). Retrieved from: http://www.canlii.org/en/on/onsc/doc/2008/2008canlii732/2008canlii732.pdf

Penny bank system explained by experts. (1908, September 11). The Ottawa Citizen, p. 3.

Pollin, R. (2003). Contours of Descent: U.S. Economic Fractures and the Landscape of Global Austerity. London: Verso.

Prager, R. (2009). Determinants of the Locations of Payday Lenders, Pawnshops and Check-Cashing Outlets. Washington: Federal Reserve.

Pryke, M. \& Du Gay, P. (2007). Take an issue: cultural economy and finance. Economy and Society, 36(3), 339-354.

Pyper, W. (2007). Payday loans. Perspectives on Labour and Income, 8(4), 5-13. 
Rip-off Report. (2011). Complaint review: Cutter Recovery - The Cash Store. Retrieved from: http://www.ripoffreport.com/collection-agency-s/cutter-recovery-the/cutterrecovery-the-cash-sto- $2842 \mathrm{~m} . \mathrm{htm}$

Rose, N., \& Miller, P. (1992). Political power beyond the state: problematics of government. British journal of sociology, 43(2), 173-205.

Rose, N. (1996). The death of the social? Re-figuring the territory of government. Economy and society, 25(3), 327-356.

Rose, N. (1999). Powers of Freedom: Reframing Political Thought. Cambridge: Cambridge UP.

Sayer, A. (2000). Moral economy and political economy, Studies in Political Economy, Spring, 79-103.

Silverthorn, M. A. (2010). The Wolf at the Door: What to Do When Collection Agencies Come Calling. McClelland \& Stewart.

Skiba, P. M. \& Tobacman, J. (2007). The Profitability of Payday Loans. Retrieved from: http://bpp.wharton.upenn.edu/tobacman/papers/profitability.pdf

Skiba, P. M. \& Tobacman, J. (2008). Payday Loans, Uncertainty and Discounting: Explaining Patterns of Borrowing, Repayment, and Default. Retrieved from: http://papers.ssrn.com/sol3/papers.cfm?abstract_id=1319751

Smart, V. (Producer). (2011, March 4). Marketplace: Debt Collector Dread. Toronto: Canadian Broadcasting Corporation.

Smiles, S. (1860). Self-Help: with illustrations of character and conduct. John Murray: London.

Smiles, S. (1875). Thrift. John Murray: London.

Special Joint Committee of the Senate and House of Commons on Consumer Credit and Cost of Living. (1967). Report on Consumer Credit. Government of Canada.

Standing Senate Committee on Banking, Trade and Commerce. (2006, June). Consumer Protection in the Financial Services Sector: The Unfinished Agenda. Retrieved from: http://www.parl.gc.ca/Content/SEN/Committee/391/bank/rep/rep02jun06e.pdf

Statistics Canada. (2010). Canadian Financial Capabilities Survey. Retrieved from: http://www.statcan.gc.ca/cgibin/imdb/p2SV.pl?Function $=$ getSurvey\&SDDS $=5159 \&$ lang $=e n \& d b=i m d b \& a d m=$ $8 \& \operatorname{dis}=2$ 
Stegman, M. (2007). Payday lending. Journal of Economic Perspectives, 21(1), 169-190.

Task Force on Financial Literacy. (2010a, September). What We Heard: A Summary of Public Consultations. Retrieved from:

http://www.financialliteracyincanada.com/documents/Summary-of-PublicConsultations-eng.pdf

Task Force on Financial Literacy. (2010b, December). Report of Recommendations on Financial Literacy: Canadians and Their Money. Retrieved from:

$\mathrm{http} / / \mathrm{www}$.financialliteracyincanada.com/pdf/canadians-and-their-money-1-reporteng.pdf

Teaching thrift in schools most valuable course. (1919, April 23). The Morning Leader, p. 10.

Thrift and the thriving. (1918, Sept. 30). The Toronto World, p. 6.

To encourage thrift. (1936, April 20). The Leader Post, p. 4.

Trentmann, F. (2006). 'The modern genealogy of the consumer: meanings, identities and political synapses' in F. Brewer \& F. Trentmann (Eds.), Consuming Cultures, Global Perspectives: Historical Trajectories, Transnational Exchanges (pp. 19-70). New York: Berg.

Under-consumption. (1936, Aug. 10). Ottawa Citizen, p. 11.

Vachon, J (Photographer). (1938). Loan Companies. Retrieved December 1, 2009 from Corbis Images website. http://www.corbisimages.com

Waldron, M. A. (2003). What is to Be Done with Section 347. Canadian Business Law Journal, $38,367$.

Walters, W. 1999: Decentering the economy. Economy and Society, 28, 312-23.

Weber, M., \& Parsons, T. (2003). The Protestant Ethic and the Spirit of Capitalism. Courier Dover Publications.

Whelan, T.S. 1979. The Pawnshop in China. Ann Arbor: Centre for Chinese Studies, University of Michigan.

Whitelaw, B. (2008, April 1). Appeal of quick cash drives proliferation of payday loans. Toronto Star. Retrieved from: http://www.thestar.com/columnists/article/407749\#article 
Williams, T. (2007). Empowerment of whom and for what? Financial literacy education and the new regulation of consumer financial services. Law \& Policy, 29(2), 226256.

Woloson, W. (2007). In hock; pawning in early America. Journal of the Early Republic, 27, 35-81.

Ziegel, J. (2003). Does Section 347 Deserve a Second Chance - A Comment. Canadian Business Law Journal, 38, 394. 